\title{
Biogeochemical constraints on the Triassic-Jurassic boundary carbon cycle event
}

\author{
D. J. Beerling \\ Department of Animal and Plant Sciences, University of Sheffield, Sheffield, England, UK
}

\author{
R. A. Berner \\ Department of Geology and Geophysics, Yale University, New Haven, Connecticut, USA \\ Received 14 September 2001; revised 6 March 2002; accepted 6 March 2002; published 18 July 2002.
}

[1] The end-Triassic mass extinctions represent one of the five most severe biotic crises in Earth history, yet remain one of the most enigmatic. Ongoing debate concerns the environmental effects of the Central Atlantic Magmatic Province (CAMP) eruptions and their linkage with the mass extinction event across the Triassic-Jurassic boundary. There is conflicting paleo-evidence for changes in atmospheric $p \mathrm{CO}_{2}$ during the extrusion of the CAMP basalts. Studies on sediments from European and Pacific localities have, however, identified a substantial negative isotopic anomaly (up to $-3.5 \%$ ) across the TR$\mathrm{J}$ boundary, providing an important indicator of changes in the operation of the ancient global carbon cycle. We sought to explain the paleo-evidence by utilizing a carbon cycle model for the "hothouse" world of the end-Triassic that emphasizes the chemical weathering of silicate and carbonate rocks and the ocean carbonate chemistry. We find that volcanic $\mathrm{CO}_{2}$ outgassing fails to fully account for either a sufficient rise in atmospheric $p \mathrm{CO}_{2}$ (indicated by the stomata of fossil leaves) or the sedimentary isotopic fingerprint. Instead, the scenario that best fits all of the geologic evidence is a positive feedback loop in which warming, due to a buildup of volcanically derived $\mathrm{CO}_{2}$, triggers destabilization of seafloor methane hydrates and the catastrophic release of $\mathrm{CH}_{4}$ [Pálfy et al., 2001]. We calculate that this carbon cycle perturbation was huge, involving the release of $\sim 8000-9000 \mathrm{Gt} \mathrm{C}$ as $\mathrm{CO}_{2}$ during the CAMP basaltic eruptions and $\sim 5000 \mathrm{Gt}$ $\mathrm{C}$ as $\mathrm{CH}_{4}$. In the model the initial isotopic excursion is assumed to take place over $\sim 70 \mathrm{kyr}$, while complete reequilibration of the ocean-atmosphere system with respect to $\mathrm{CO}_{2}$ is accomplished over $700-1000$ kyr. Our results thus provide a preliminary theoretical explanation for the bioevents, estimated $p \mathrm{CO}_{2}$ changes, and isotopic excursions observed in marine and continental sediments at this time. INDEX TERMS: 0325 Atmospheric Composition and Structure: Evolution of the atmosphere; 1615 Global Change: Biogeochemical processes (4805); 0370 Atmospheric Composition and Structure: Volcanic effects (8409); 1060 Geochemistry: Planetary geochemistry (5405, 5410, 5704, 5709, 6005, 6008); KEYWORDS: Triassic, Jurassic, carbon, Central Atlantic Magmatic Province, global change

\section{Introduction}

[2] The boundary between the Triassic (TR) and Jurassic (J) epochs, $\sim 200$ million years (Myr) ago [Pálfy et al., 2000a], is marked by one of the five largest mass extinction events in Earth history [Sepkosky, 1996]. Fossil evidence indicates that $\sim 80 \%$ of living species went extinct; this represents a degree of severity exceeding that seen across the Cretaceous-Tertiary boundary and included the loss of $53 \%$ of marine genera and $50 \%$ of tetrapod species [Sepkosky, 1996]. Terrestrial vegetation also suffered a sudden and severe crisis at the boundary. North American

Copyright 2002 by the American Geophysical Union. 0886-6236/02/2001GB001637\$12.00 palaeobotanical studies in the Newark basin reveal the loss of $60 \%$ of palynospecies at the boundary, together with a proliferation of fern species [Fowell and Olsen, 1993]. In the North Atlantic region, even more severe ecological trauma occurred, with a $>95 \%$ turnover of megafloral species [Harris, 1935, 1937; Lundblad, 1959] and marked microfloral turnovers [Visscher and Brugman, 1981].

[3] Despite the severity of the TR-J boundary mass extinctions, associated environmental changes have been poorly documented in comparison to other extinction episodes [Wignall, 2001], a situation arising in part from the relative scarcity of complete marine sections lacking diagenesis and reworking of sediments. In consequence, the causal mechanisms driving the end-Triassic extinctions continue to remain enigmatic [Hallam and Wignall, 1997]. 
Key issues of uncertainty relate to whether the biogeochemical cycling of carbon, and other elements, underwent a major perturbation across the boundary and, if this occurred, how it was linked with changes in global climate and the isotopic composition of the oceanic, terrestrial, and atmospheric carbon reservoirs [McElwain et al., 1999; Ward et al., 2001; Pálfy et al., 2001, 2002; Beerling, 2002; Hesselbo et $a l ., 2002]$. It is also likely that mass extinctions in the terrestrial and marine realms themselves influenced the role of biota in the exchange of carbon between reservoirs [McRoberts et al., 1997; Ward et al., 2001].

[4] The first evidence pointing to a significant carbon cycle event across the TR-J boundary derives from detailed studies of the stomatal characters and isotopic composition of fossil Ginkgoalean and Cycadalean leaves from Greenland and Sweden [McElwain et al., 1999]. Using the stomatal approach to estimating paleo- $\mathrm{CO}_{2}$ levels, $\mathrm{McEl}$ wain et al. [1999] reconstructed an increase in atmospheric $\mathrm{CO}_{2}$ concentration $\left(p \mathrm{CO}_{2}\right)$ of $\sim 1400 \mathrm{ppm}$ across the boundary. Coincident with the $p \mathrm{CO}_{2}$ rise and terrestrial mass extinctions [Pálfy et al., 2000a] was the geologically rapid [Olsen et al., 1996; Hames et al., 2000; Cohen and Coe, 2002] emplacement of the Central Atlantic Magmatic Province (CAMP), a continental flood basalt province extending over an area $>2.5 \times 10^{6} \mathrm{~km}^{2}$ in northern and central Brazil, western Africa, and the eastern United States [Marzoli et al., 1999]. Taken together, these observations suggest a linkage between the TR-J boundary mass extinction, the release of significant amounts of $\mathrm{CO}_{2}$ by CAMP volcanic activity, and catastrophic greenhouse warming. However, this coupling between mantle $\mathrm{CO}_{2}$ outgassing and extinctions has been questioned by a study on the carbon isotope composition of North American Late Triassic and Early Jurassic pedogenic carbonates [Tanner et al., 2001]. Calibrated with a diffusion-reaction model [Cerling, 1991, 1992], the minor change in paleosol isotopic composition $\left(0.3 \%\right.$ ) corresponds to a modest $\mathrm{CO}_{2}$ rise of $\sim 250$ ppm, i.e., a relatively stable atmospheric carbon reservoir across the TR-J boundary.

[5] A second line of evidence indicating a disturbance of the carbon cycle across the TR-J boundary comes in the form of a negative isotopic excursion recorded in both organic and inorganic carbon pools [McElwain et al., 1999; Ward et al., 2001; Pálfy et al., 2001, 2002; Hesselbo et al., 2002]. Fossilized land plant leaves from a lacustrine section in Greenland show a negative 3\%o excursion between the Rhaetian and Hettangian stages of the Triassic and Jurassic, respectively [McElwain et al., 1999]. Further studies from sites elsewhere in the world indicate that his might be a rather general phenomenon characterizing continental and marine TR-J boundary sediments, in common with mass extinctions during the Permo-Triassic [Holser et al., 1989] and Cretaceous-Tertiary [Hsü et al., 1982]. Ward et al. [2001] reported a negative $2 \%$ oxcursion in bulk organic matter from a sedimentary sequence in the Queen Charlotte Islands, British Columbia, Canada, and Pálfy et al. [2001] identified a negative 3.5 and $2 \%$ excursion in marine carbonates and bulk organic matter, respectively, from Hungary. The excursions in both Hungary and British Columbia sections are abrupt, well above the background variation in the rest of the sections and coincident with the sudden extinctions of marine organisms.

[6] Reconciling the paleo-evidence for atmospheric $p \mathrm{CO}_{2}$ and the coincident sedimentary carbon isotopic fingerprint across the TR-J boundary now represents a central task if we are to decipher cause and effect during the end-Triassic mass extinctions. This aim represents the main objective of the present paper. Our approach has been to first revisit the stomatal and paleosol evidence for atmospheric $p \mathrm{CO}_{2}$ change across the TR-J boundary to consider uncertainties inherent in both proxies [Royer et al., 2001] to develop a revised set of $p \mathrm{CO}_{2}$ curves. We next adopt a model-based approach to quantify the effect of mantle $\mathrm{CO}_{2}$ outgassing during the emplacement of the CAMP basalts on atmospheric $p \mathrm{CO}_{2}$ levels and the carbon isotopic composition of the organic and inorganic carbon reservoirs. Our model, which accounts for the chemical weathering of terrestrial silicate and carbonate rocks and for ocean chemistry, is a modified version of the time-dependent Berner, Lasaga, and Garrels (BLAG) model [Berner et al., 1983], specifically designed for analyzing carbon cycle perturbations during the end-Triassic "greenhouse" world. Included in our modeling analyses is an assessment of possible positive feedback effects of a sudden release of isotopically light $\mathrm{CH}_{4}$ from the marine sedimentary reservoir, postulated by Pálfy et al. [2001, 2002] to be a primary driver of the isotopic excursion. The revised atmospheric $p \mathrm{CO}_{2}$ curves, together with the stable carbon isotope records from marine and lacustrine sections, are then used as a basis for evaluating the model results to determine which scenario best represents the carbon cycle event across the TR-J boundary.

\section{Paleobiological Evidence for a $p \mathrm{CO}_{2}$ Increase Across TR-J Boundary}

\subsection{Stomatal Evidence}

[7] Quantitative reconstructions of $p \mathrm{CO}_{2}$ from stomatal characters of fossil leaves and the isotopic composition of pedogenic carbonates both have sources of error attached to them [Royer et al., 2001; Ekart et al., 1999]. The stomatal technique utilizes the established inverse correlation between the stomatal index (percentage of leaf surface cells that are stomatal pores) of land plant leaves and atmospheric $p \mathrm{CO}_{2}$ [Woodward, 1987]. Direct measurements of stomatal index on fossil cuticles of Ginkgoalean and Cycadalean leaves from sections in Jameson Land, east Greenland (Cape Stewart formation), and Scania, southern Sweden, indicate marked reductions across the TR-J boundary [McElwain et al., 1999]. In fact, fossil leaves of some taxa from particular horizons have exceptionally low stomatal indices $(\sim 3-4)$, values not observed in modern plants and only previously recorded on the fossil axes of early land plants growing in the inferred Devonian high- $p \mathrm{CO}_{2}$ environment [Edwards, 1998]. These observations are qualitatively consistent with vegetation responding to a major paleo- $\mathrm{CO}_{2}$ increase $\sim 200 \mathrm{Myr}$ ago.

[8] Atmospheric $p \mathrm{CO}_{2}$ levels were quantitatively reconstructed [McElwain et al., 1999] with stomatal ratios, whereby the stomatal index of the modern equivalent divided by that of the fossil (i.e., the stomatal ratio, SR) is directly related to the ratio of atmospheric $\mathrm{CO}_{2}$ in the past 

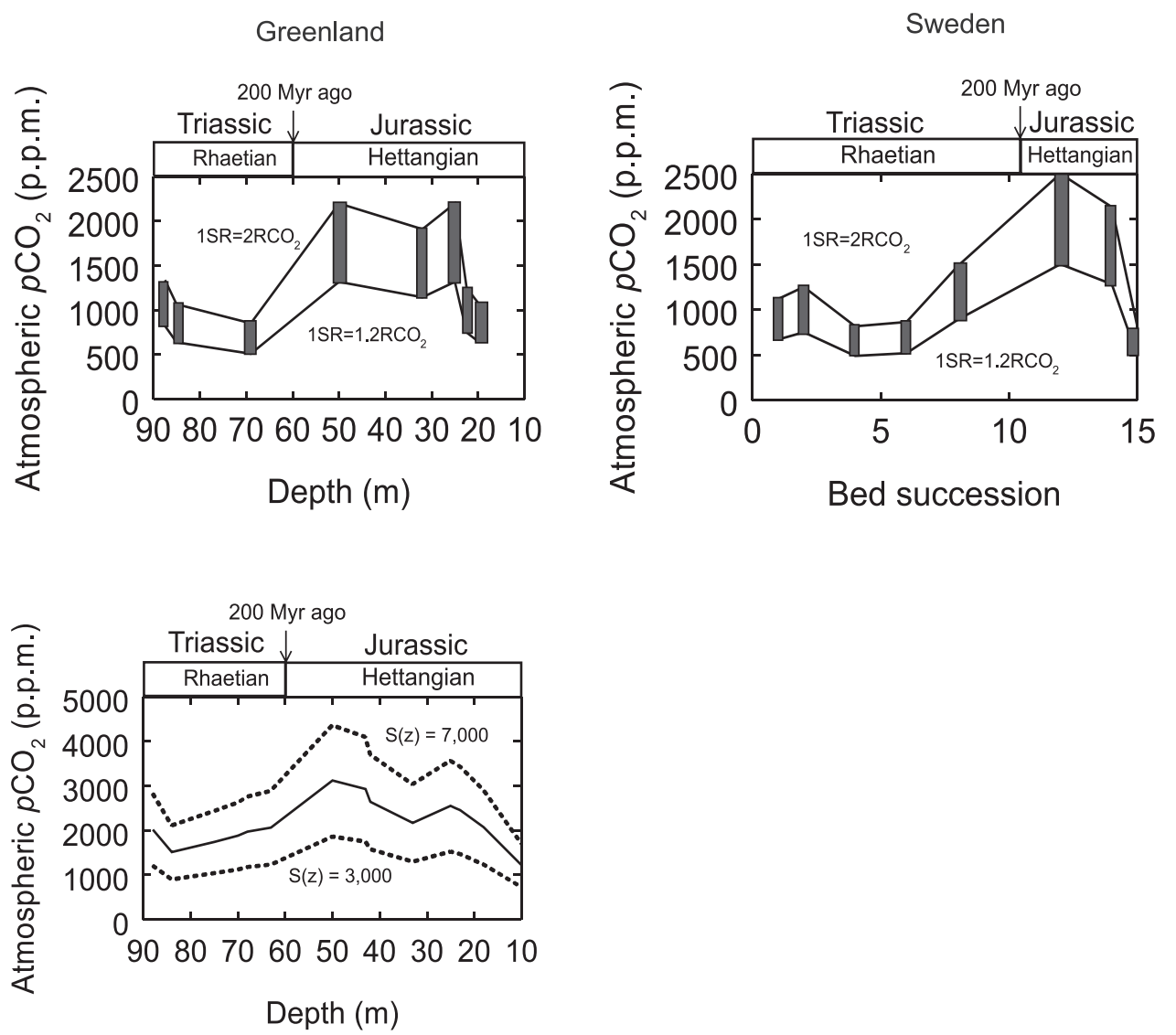

Figure 1. Reconstructed changes in atmospheric $p \mathrm{CO}_{2}$ levels over Triassic-Jurassic boundary based on stomatal indices of fossil leaves from Greenland (top left) and from Sweden (top right). Range was calculated by calibrating stomatal ratios (SR) of fossils as being equal to either 1.2 or 2 times the ratio of atmospheric $\mathrm{CO}_{2}$ in the past relative to the present $\left(R \mathrm{CO}_{2}\right)$. Range was recalculated from original data of McElwain et al. [1999]. For comparison, changes in atmospheric $p \mathrm{CO}_{2}$ reconstructed using paleosol $p \mathrm{CO}_{2}$ barometer with pedogenic carbonate data of Tanner et al. [2001] and stable carbon isotope signature of terrestrial organic matter from Greenland are displayed (bottom left) [after Beerling, 2002]. Upper and lower lines are determined by setting $S(z)$ to either 7000 or 3000 ppm $\mathrm{CO}_{2}$, respectively. See text for further details.

relative to the present day $\left(\mathrm{RCO}_{2}\right)$ [McElwain and Chaloner, 1996; Chaloner and McElwain, 1997]. Two calibrations have been suggested on the basis of a comparison of fossil and modern plant materials against the $\mathrm{CO}_{2}$ curve calculated from a geochemical long-term carbon cycle model [Berner, 1994], yielding $1 \mathrm{SR}=600$ ppm [McElwain and Chaloner, 1996], and 1 SR $=450 \mathrm{ppm}$ [McElwain, 1998]. The method assumes a priori a nonlinear relationship between the stomatal index of a fossil and $\mathrm{CO}_{2}$. However, for Ginkgo, the SR-derived calibration curve matches reasonably well observations on modern historical sequences of leaves, and leaves grown experimentally under a range of atmospheric $\mathrm{CO}_{2}$ concentrations, providing support for the approach [Beerling and Royer, 2002].

[9] We used the two SR calibrations to calculate likely upper and lower bound $p \mathrm{CO}_{2}$ estimates from the stomatal indices of leaves at a given depth in a particular section. Proceeding on this basis, we recalculated atmospheric $p \mathrm{CO}_{2}$ levels using the stomatal index data reported for fossil leaves from east Greenland and southern Sweden $[\mathrm{McEl}$ - wain et al., 1999] (Figure 1). Our reanalysis confirms the reported rise in atmospheric $p \mathrm{CO}_{2}$ across the TR-J boundary reported by McElwain et al. [1999]. Taking the mean of the upper and lower $p \mathrm{CO}_{2}$ estimates, we reconstruct end-Triassic values of 872 and 884 ppm for Greenland and Sweden, respectively, which are both within the range calculated from a long-term geochemical model of the carbon cycle [Berner and Kothavala, 2001]. By the earliest Jurassic, atmospheric $p \mathrm{CO}_{2}$ is reconstructed to have risen by between +810 ppm (Greenland) and +1120 ppm (Sweden) (Figure 1), increases smaller than originally estimated [McElwain et al., 1999], but nevertheless substantially greater than that implied by the paleosol isotope data $(250$ ppm) [Tanner et al., 2001].

\subsection{Paleosol Evidence}

[10] Estimation of any transient atmospheric $p \mathrm{CO}_{2}$ changes across the TR-J boundary using the paleosol $\mathrm{CO}_{2}$ barometer [Cerling, 1991, 1992] requires isotopic analyses of pedogenic carbonates and coeval terrestrial organic 
matter $\left(\delta^{13} \mathrm{C}_{\mathrm{OM}}\right)$ with a high stratigraphic resolution. An initial study of terrestrial pedogenic carbonates between the late Triassic to early Jurassic showed a distinct negative isotope excursion over this time [Suchecki et al., 1988]. Calibrated with the paleosol $\mathrm{CO}_{2}$ model, the shift corresponds to a rise in atmospheric $p \mathrm{CO}_{2}$ of $>1000 \mathrm{ppm}$. However, although this increase is intriguing, the use of some of the isotopic data for this purpose may be compromised by inadequate controls on sample selection [Ekart et al., 1999]. In a more recent study, Tanner et al. [2001] obtained pedogenic calcite samples from sites dated to the Upper Triassic (Carnian and Norian) and the Lower Jurassic (Hettangian). These samples thus ranged over $20 \mathrm{Myr}$, a temporal resolution considerably lower than the study of fossil leaves [McElwain et al., 1999]. The upper Triassic sample is likely to predate the onset of any $\mathrm{CO}_{2}$ outgassing from the CAMP eruptions [Hames et al., 2000; Pálfy et al., 2002; Beerling, 2002]. Their atmospheric $p \mathrm{CO}_{2}$ estimate for the Hettangian paleosol however is, at $2480 \mathrm{ppm}$, in line with the stomatal evidence (Figure 1).

[11] A well-characterized requirement of the paleosol $\mathrm{CO}_{2}$ barometer is the need to constrain the isotopic composition of organic matter $\left(\delta^{13} \mathrm{C}_{\mathrm{OM}}\right)$ [Cerling, 1991, 1992]. This sensitivity arises because $\delta^{13} \mathrm{C}_{\mathrm{OM}}$ represents the isotopic composition of soil respired $\mathrm{CO}_{2}$, a significant flux relative to the back diffusion of $\mathrm{CO}_{2}$ into the soil from the atmosphere. Tanner et al. [2001] assumed a constant $\delta^{13} \mathrm{C}_{\mathrm{OM}}$ value to calculate atmospheric $p \mathrm{CO}_{2}$ values for the Norian and the Hettangian. However, the $\delta^{13} \mathrm{C}_{\mathrm{OM}}$ excursion shown by fossil land plant leaves in Greenland, and bulk organic matter from Canada [Ward et al., 2001] and Hungary [Pálfy et al., 2001] indicates this is unlikely to be correct. An alternative interpretation of the paleosol data is therefore possible in which the late Triassic and early Jurassic samples provide end-member constraints, and the diffusion reaction model of Cerling [1991, 1992] is forced with the $\delta^{13} \mathrm{C}_{\mathrm{OM}}$ records of terrestrial plant leaves [Beerling, 2002]. Calculated in this way, atmospheric $p \mathrm{CO}_{2}$ increases by $1032 \mathrm{ppm}$, a rise consistent with the $\mathrm{CO}_{2}$ reconstructions based on fossil leaf cuticles (Figure 1) [Beerling, 2002].

[12] Our reanalysis of the stomatal and paleosol paleo$p \mathrm{CO}_{2}$ proxies consistently indicates that within the uncertainties associated with the different approaches, atmospheric $p \mathrm{CO}_{2}$ levels rose by around +810 to $+1120 \mathrm{ppm}$ across the TR-J boundary. The revised $p \mathrm{CO}_{2}$ reconstructions therefore require an explanation that, additionally, must also be consistent with the isotopic signals in sediments from Tethyan [Pálfy et al., 2001; Hesselbo et al., 2002] and Pacific [Ward et al., 2001] localities.

\section{Carbon Cycle Greenhouse Model}

3.1. Carbon Reservoir Masses, Fluxes, and Exchanges

[13] We have addressed these issues through the development and application of a carbon cycle model for the endTriassic greenhouse world. The carbon cycle model is a modification of the earlier BLAG model of Berner et al. [1983] and is illustrated in Figure 2. The BLAG model is modified by lumping $\mathrm{Ca}$ with $\mathrm{Mg}$ and by introducing a

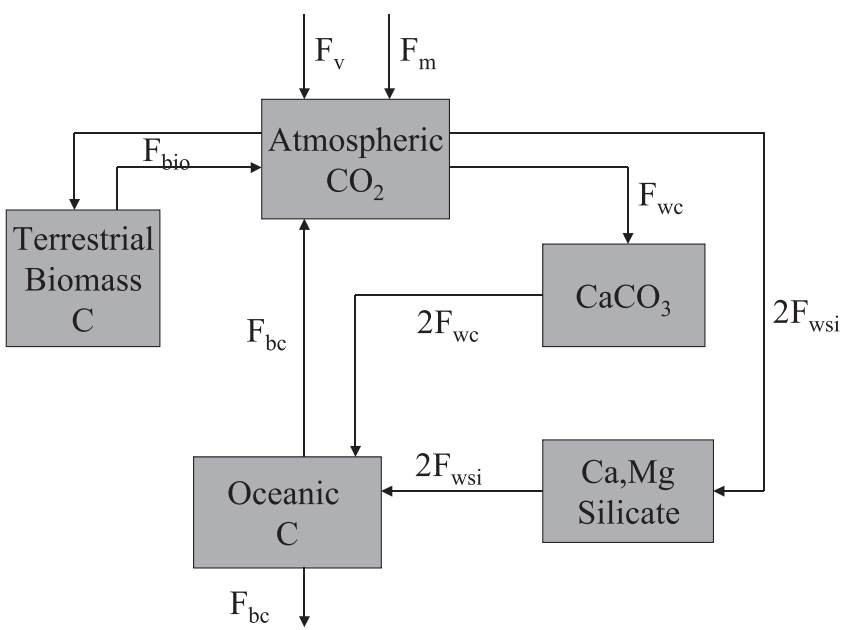

Figure 2. Schematic diagram of the end-Triassic greenhouse world carbon cycle. Carbon inputs to atmosphere are denoted by $F_{v}=\mathrm{CO}_{2}$ from volcanism, $F_{m}=\mathrm{CH}_{4}$ from seafloor methane hydrates, and $F_{\mathrm{bc}}=$ precipitation of carbonates in the oceans. Carbon is removed from atmosphere by weathering of $\mathrm{Ca}-\mathrm{Mg}$ carbonates $\left(F_{\mathrm{wc}}\right)$ and silicates $\left(F_{\mathrm{wsi}}\right)$. Carbon exchange between atmosphere and terrestrial biosphere is also indicated $\left(F_{\text {bio }}\right)$.

methane flux to the atmosphere where $\mathrm{CH}_{4}$ is rapidly oxidized to $\mathrm{CO}_{2}$. Carbon is added to the atmosphere by volcanism $\left(F_{v}\right)$, the decomposition of methane hydrates $\left(F_{m}\right)$, and the precipitation of carbonates in the ocean $\left(F_{\mathrm{bc}}\right)$ and is lost from the atmosphere by the weathering of Ca-Mg carbonates $\left(F_{\mathrm{wc}}\right)$ and silicates $\left(F_{\mathrm{wsi}}\right)$. There is also exchange of carbon between the terrestrial biosphere and the atmosphere $\left(F_{\text {bio }}\right)$. Carbon is added to the oceans by carbonate and silicate weathering and is lost via carbonate precipitation.

[14] The appropriate generalized silicate and carbonate reactions [e.g., see Berner, 1998], with $\mathrm{Ca}+\mathrm{Mg}$ represented simply as $\mathrm{Ca}$, are

For weathering

$$
\begin{gathered}
\mathrm{CaSiO}_{3}+2 \mathrm{CO}_{2}+\mathrm{H}_{2} \mathrm{O} \rightarrow \mathrm{Ca}^{2+}+2 \mathrm{HCO}_{3}^{-}+\mathrm{SiO}_{2}, \\
\mathrm{CaCO}_{3}+\mathrm{CO}_{2}+\mathrm{H}_{2} \mathrm{O} \rightarrow \mathrm{Ca}^{2+}+2 \mathrm{HCO}_{3}^{-},
\end{gathered}
$$

For carbonate deposition in the oceans

$$
2 \mathrm{HCO}_{3}^{-}+\mathrm{Ca}^{2+} \rightarrow \mathrm{CaCO}_{3}+\mathrm{CO}_{2}+\mathrm{H}_{2} \mathrm{O} .
$$

The long-term organic subcycle [Berner, 1998], involving the weathering and sedimentary burial of organic matter, is assumed to be at steady state over the short time scale considered here. Also, methane released to the atmosphere is oxidized very rapidly to $\mathrm{CO}_{2}$ with a mean residence time of 10 years (as in the modern atmosphere) so that a steady state mass of methane $(M)$ is present at all times $\left(M=F_{m} / k\right.$, where $k=10^{5} \mathrm{Myr}^{-1}$ ). Rapid oxidation, for the alternative situation of $\mathrm{CH}_{4}$ release directly to the oceans, is also assumed [Dickens, 2000]. 
[15] In our model, mass balance expressions are constructed for carbon and for calcium. For atmospheric carbon $(C)$ this gives

$$
\frac{\mathrm{d} C}{\mathrm{~d} t}=F_{v}+F_{m}+F_{\mathrm{bc}}-F_{\mathrm{wc}}-2 F_{\mathrm{wsi}}-F_{\mathrm{bio}} .
$$

Note that $F_{\text {bio }}$ can be $<0$ for loss of terrestrial biomass.

For oceanic carbon $\left(C_{w}\right)$

$$
\frac{\mathrm{d} C_{w}}{\mathrm{~d} t}=2 F_{\mathrm{wsi}}+2 F_{\mathrm{wc}}-2 F_{\mathrm{bc}},
$$

For oceanic calcium

$$
\frac{\mathrm{d} M_{\mathrm{ca}}}{\mathrm{d} t}=F_{\mathrm{wsi}}+F_{\mathrm{wc}}-F_{\mathrm{bc}},
$$

where $C$ is mass of carbon (as $\mathrm{CO}_{2}$ ) in the atmosphere, $C_{w}$ is mass of carbon (as $\mathrm{HCO}_{3}^{-}$) dissolved in the oceans, $M_{\mathrm{ca}}$ is the mass of calcium dissolved in the oceans, flux terms $F$ are defined above, and $t=$ time. For simplicity of calculation, all masses were expressed as $10^{18} \mathrm{~mol}$ and fluxes $(F)$ were expressed in $10^{18} \mathrm{~mol} \mathrm{Myr}^{-1}$. However, to compare with the literature, the results have been converted in this paper to $\mathrm{Gt} \mathrm{C}$ and $\mathrm{Gt} C \mathrm{kyr}^{-1}$.

[16] Silicate and carbonate weathering rate was assumed to be a simple function of temperature, which is in turn a greenhouse function of the $\mathrm{CO}_{2}$ and $\mathrm{CH}_{4}$ contents of the atmosphere and is given by [Berner and Kothavala, 2001]

$$
\begin{aligned}
& \frac{F_{\mathrm{wsi}}(T)}{F_{\mathrm{wsi}}\left(T_{0}\right)}=\exp \left[0.09\left(T-T_{0}\right)\right] \\
& \frac{F_{\mathrm{wc}}(T)}{F_{\mathrm{wc}}\left(T_{0}\right)}=\exp \left[0.09\left(T-T_{0}\right)\right],
\end{aligned}
$$

where $T=$ temperature and subscript 0 refers to the initial state. A simple representation of greenhouse warming is given by (modified from Berner and Kothavala [2001] and Schrag et al. [2002])

$$
T-T_{0}=\Gamma_{\mathrm{mc}} \ln \left[\frac{(C+\lambda M)}{\left(C_{0}+\lambda M_{0}\right)}\right],
$$

where $\Gamma_{\mathrm{mc}}$ refers to the combined methane plus $\mathrm{CO}_{2}$ greenhouse response, $\lambda$ is the ratio of the greenhouse response of methane per molecule to that of $\mathrm{CO}_{2}, C_{0}$ and $M_{0}$ are mass of carbon dioxide and methane, respectively, in the initial atmosphere. From global climate model (GCM) results applied to a warm climate [Berner and Kothavala, 2001], $\Gamma_{\mathrm{mc}}=4^{\circ} \mathrm{C}$, and $\lambda=25$. Equations (4)(6) can then be combined and rearranged to solve for $F_{\text {wsi }}(T)$ and $F_{\text {wc }}(T)$.

[17] For the carbonate precipitation and burial flux, $F_{\mathrm{bc}}$, the approach of Berner et al. [1983] was used:

$$
F_{\mathrm{bc}}=\operatorname{kpp}\left(M_{\mathrm{ca}} C_{w}^{2}-K C\right),
$$

where kpp is a rate constant and $K$ is the "equilibrium constant" for reaction (iii) above in terms of global molar masses of oceanic calcium, oceanic bicarbonate, and atmospheric carbon dioxide. Values of kpp and $K$ are calculated so that an initial steady state value of $F_{\mathrm{bc}}(0)=$ $F_{\mathrm{wsi}}(0)+F_{\mathrm{wc}}(0)$ is obtained and also so that the product $\operatorname{kpp} K=(\text { mean oceanic turnover time })^{-1}$ [Berner et al., 1983]. To satisfy these criteria, the values $K=2000\left(10^{18}\right.$ $\mathrm{mol})^{2}$ and $\mathrm{kpp}=0.759\left(10^{18} \text { moles }\right)^{-2} \mathrm{Myr}^{-1}$ were used, giving a mean oceanic turnover time of 660 years.

[18] The expression for the uptake or release of carbon by the terrestrial biosphere, $F_{\text {bio }}$, is based on a function integrating the effects of changes in global mean temperature and atmospheric $\mathrm{CO}_{2}$ level on the carbon stocks of vegetation and soils [Beerling et al., 2002]. The function represents a fitted response surface to multiple simulations defining the sensitivity of terrestrial carbon storage described by a process-based model of the terrestrial carbon cycle and a global paleoclimate model simulation of the late Jurassic [Beerling, 2000]. The terrestrial carbon cycle model [Woodward et al., 1995] accounts for the effects of climate and atmospheric composition on photosynthetic primary production, vegetation biomass, autotrophic and heterotrophic respiration, and soil organic matter dynamics. At each small time step, global net changes in carbon storage by the terrestrial biosphere are calculated, and the flux $F_{\text {bio }}$ is estimated as the change in biomass between $t$ and $t-1$.

\subsection{Carbon Isotope Mass Balance}

[19] The carbon isotopic composition for seawater was calculated from mass balance expressions for the ocean (equation (2)) and for the combined ocean and atmosphere:

$$
\begin{gathered}
\frac{\mathrm{d}\left(C+C_{w}\right)}{\mathrm{d} t}=F_{v}+F_{m}+F_{\mathrm{wc}}-F_{\mathrm{bc}}-F_{\mathrm{bio}} \\
\frac{\mathrm{d}\left(\delta_{a} C+\delta_{w} C_{w}\right)}{\mathrm{d} t}=\delta_{v} F_{v}+\delta_{m} F_{m}+\delta_{\mathrm{wc}} F_{\mathrm{wc}}-\delta_{\mathrm{bc}} F_{\mathrm{bc}}-\delta_{\mathrm{bio}} F_{\mathrm{bio}},
\end{gathered}
$$

where $\delta \% 0)=\left[\left({ }^{13} \mathrm{C} /{ }^{12} \mathrm{C}\right) /\left({ }^{13} \mathrm{C} /{ }^{12} \mathrm{C}\right)\right.$ stnd -1$] 1000, \delta_{a}$ refers to atmospheric $\mathrm{CO}_{2}$, and $\delta_{w}$ refers to oceanic dissolved inorganic carbon. Introducing the simplifications that the ocean and atmosphere are in isotopic equilibrium $\left(\delta_{a}=\delta_{w}-\right.$ $7 \%$ ), that $\delta_{\mathrm{bc}}$ is the same as that for the oceans $\delta_{w}$, and that fractionation via terrestrial photosynthesis is $\sim 19 \%$ o $\left(\delta_{\text {bio }}=\right.$ $\delta_{a}-19 \%$ ), we get, by combining equations (2), (8), and (9), and solving for $\delta_{w}$,

$$
\begin{aligned}
\frac{\mathrm{d}\left(\delta_{w}\right)}{\mathrm{d} t}= & {\left[\left(\delta_{v}-\delta_{w}+7\right) F_{v}+\left(\delta_{m}-\delta_{w}+7\right) F_{m}\right.} \\
& +\left(\delta_{\mathrm{wc}}-\delta_{w}+7\right) F_{\mathrm{wc}}-7 F_{\mathrm{bc}}+19 F_{\mathrm{bio}} \\
& \left.-7\left(2 F_{\mathrm{wsi}}+2 F_{\mathrm{wc}}-2 F_{\mathrm{bc}}\right)\right] /\left(C+C_{w}\right) .
\end{aligned}
$$

\subsection{Computational Method}

[20] All simulations used a simple Eulerian numerical computation with a time step of 500 years. Initial values were taken for a steady state silicate-carbonate cycle based on the results of Berner and Kothavala [2001] for $200 \mathrm{Myr}$ ago. They are (in $10^{18} \mathrm{~mol}$ or $10^{18} \mathrm{~mol} \mathrm{Myr}^{-1}$ ) $C_{0}=0.25$, $(1500 \mathrm{ppm}), M_{0}=1.67 \times 10^{-4}(1 \mathrm{ppm}), F_{v}(0)=7, F_{m}(0)=0$, $F_{\mathrm{wsi}}(0)=7, F_{\mathrm{wc}}(0)=30$, and $F_{\mathrm{bc}}(0)=37$. Initial oceanic values for $M_{\mathrm{ca}}$ and $C_{w}$ were calculated for equilibrium via reaction (iii) to be $M_{\mathrm{ca}}=15.569, C_{w}=5.937$. Isotopic 
Table 1. $\mathrm{CO}_{2}$ Degassing Rates During Volcanic Eruptions and Estimated Volume of Central Atlantic Magmatic Province (CAMP) Basalts

\begin{tabular}{lclccc}
\hline & $\begin{array}{c}\mathrm{CO}_{2} \text { Degassing, } \\
\mathrm{g} \mathrm{km}{ }^{-3} \text { basalt }\end{array}$ & \multicolumn{1}{c}{ Reference } & $\begin{array}{c}\mathrm{CAMP} \text { Volume, } \\
\mathrm{km}^{3 \mathrm{a}}\end{array}$ & $\begin{array}{c}\text { Total CO } \mathrm{CO}_{2} \text { Released, } \\
\mathrm{Gt} \mathrm{CO}_{2}^{\mathrm{b}}\end{array}$ & $\begin{array}{c}\text { Total C Released, } \\
\mathrm{Gt} \mathrm{C}^{\mathrm{b}}\end{array}$ \\
\hline Lower bounds & $3.5 \times 10^{12}$ & Leavitt [1982] & $2 \times 10^{6}$ & 7000 & 1900 \\
& $1.6 \times 10^{13}$ & Gerlach and Graeber [1985] & $2 \times 10^{6}$ & 32,000 & 8727 \\
Upper bounds & $3.5 \times 10^{12}$ & Leavitt [1982] & $4 \times 10^{6}$ & 14,000 & 3800 \\
& $1.6 \times 10^{13}$ & Gerlach and Graeber [1985] & $4 \times 10^{6}$ & 64,000 & 17,454 \\
\hline
\end{tabular}

${ }^{\mathrm{a}}$ Upper and lower estimate basalt volume from Marzoli et al. [1999] and Olsen [1999], respectively.

${ }^{\mathrm{b}} 1 \mathrm{Gt}=10^{15} \mathrm{~g}$.

compositions (\%o) assumed were $\delta_{v}=-6, \delta_{m}=-60, \delta_{\mathrm{wc}}=2$, and initial $\delta_{w}=0.6$. A control simulation with the initial steady state conditions for $2 \mathrm{Myr}$, and with no extra methane or volcanic $\mathrm{CO}_{2}$, showed a drift of $<1 \mathrm{ppm} \mathrm{CO}_{2}$ and $<0.1 \%$ in $\delta_{w}$ due to arithmetic rounding.

\section{Simulations of Environmental Change Due to CAMP Eruptions}

\section{1. $\mathrm{CO}_{2}$ Degassing During CAMP Eruptions}

[21] To calculate rates of $\mathrm{CO}_{2}$ production during the eruption of continental flood basalts, it is necessary to first have some idea of the mass of $\mathrm{CO}_{2}$ emitted per unit volume of basalt erupted. There are two such estimates that can be used to set the upper and lower bounds (Table 1). The higher proportion of $\mathrm{CO}_{2}$ is based on the volatile budget data for Kilauea derived from observations over a 27 -year period [Gerlach and Graeber, 1985]. The lower proportion is derived from Leavitt's [1982] empirical relationship relating the number of moles of $\mathrm{CO}_{2}$ emitted during an eruption to its magnitude.

[22] The total mass of $\mathrm{CO}_{2}$ emitted during the CAMP eruptions is calculated as the product of a given $\mathrm{CO}_{2}$ emission per unit volume of basalt and the total volume of CAMP volcanics. Initially, the volume of basalts associated with the breakup of the Central Atlantic region in the Early Jurassic was estimated to be rather modest $\left(\sim 50,000 \mathrm{~km}^{3}\right)$ [McHone, 1996]. However, the realization that the basalts were in place before continental rifting took place [Deckart et al., 1997] led to the recognition of their widespread distribution [Marzoli et al., 1999]. CAMP is estimated to cover a total area in excess of $7 \times 10^{6} \mathrm{~km}^{2}$, conservatively assumed to correspond to a volume of $2 \times 10^{6} \mathrm{~km}^{3}$. Circumstantial evidence suggests that seaward dipping reflectors off the eastern United States may also be part of CAMP, although the dating is poorly constrained [Olsen, 1999]. Inclusion of the volume of these purported terrestrial flows would double the total CAMP volume to $4 \times 10^{6} \mathrm{~km}^{3}$, and even this can be regarded as a conservative estimate if the intrusive volume of CAMP is considered. Therefore we set the upper and lower bounds for the CAMP volume at $2 \times$ $10^{6} \mathrm{~km}^{3}$ and $4 \times 10^{6} \mathrm{~km}^{3}$, respectively.

\subsection{Mantle $\mathrm{CO}_{2}$ Degassing Scenarios}

[23] Four simulations of the effects of volcanic $\mathrm{CO}_{2}$ emissions from the CAMP basalts on the evolution of atmospheric $\mathrm{CO}_{2}$, global mean surface temperature (equation (6)), the carbon isotopic composition and storage of terrestrial organic carbon (vegetation biomass and soil organic matter) were undertaken. In each simulation the magnitude of $F_{v}$ (volcanic degassing) was varied to give total emissions of (1) 1326, (2) 7957, (3) 13,262, and (4) 21,220 Gt $\mathrm{C}$ (Figure 3). The first and second scenarios encompass the estimates assuming a CAMP volume of $2 \times$ $10^{6} \mathrm{~km}^{3}$ (Figure 3 and Table 1), while all four scenarios provide a range of possible emissions for the higher CAMP volume of $4 \times 10^{6} \mathrm{~km}^{3}$ (Figure 3 and Table 1). The fourth scenario was included to set an extreme upper limit of $\mathrm{CO}_{2}$ degassing during the CAMP eruptions.

[24] In order to run the simulations in a reasonably realistic manner, $F_{v}$ was assumed to follow a Gaussian-type time distribution with a degassing peak at $250 \mathrm{kyr}$ after the start of a simulation and with a peak half-height time of $\pm 100 \mathrm{kyr}$. This sets the duration for $\mathrm{CO}_{2}$ production at 500 $\mathrm{kyr}$, in agreement with dating evidence suggesting shortlived peak intensity at $\sim 200$ Myr ago [Marzoli et al., 1999], lasting for $\sim 580 \pm 100 \mathrm{kyr}$ [Olsen et al., 1996].
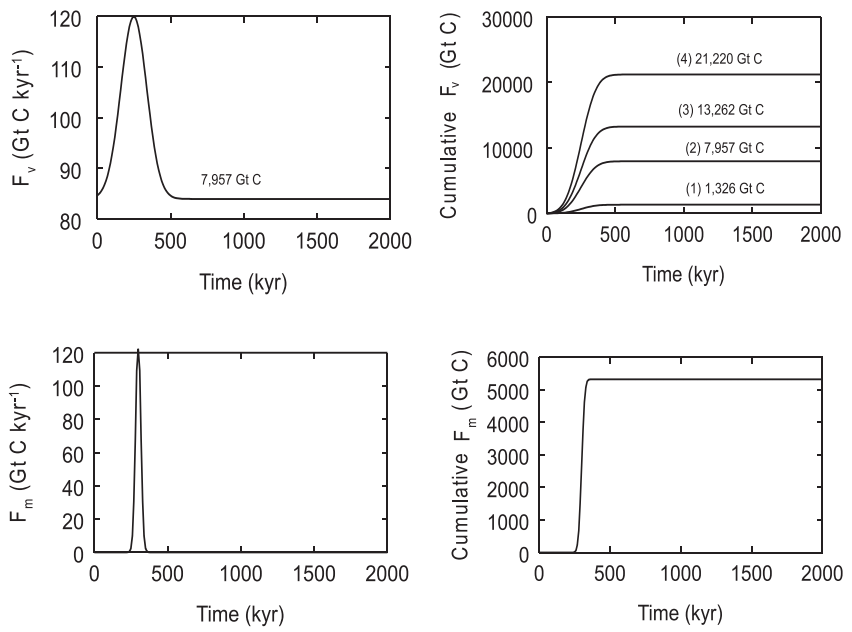

Figure 3. Example of Gaussian distribution of volcanic $\mathrm{CO}_{2}$ degassing rates $\left(F_{v}\right)$ (top left) and $\mathrm{CH}_{4}$ (bottom left) release $\left(F_{m}\right)$ from methane hydrates over time used as inputs into various carbon cycle simulations. $F_{v}$ plot is an example corresponding to cumulative excess release of $7957 \mathrm{Gt} \mathrm{C}$; $F_{v}$ plots for other cumulative amounts show same time distribution but different peak values. $F_{m}$ plot is same for all scenarios. Top and bottom right depict the four cumulative excess (above background) $\mathrm{CO}_{2}$ release scenarios (Table 1) and that of $\mathrm{CH}_{4}$, respectively. Note that $F_{v}$ and $F_{m}$ are not maintained at above background rates for more than 500 and $50 \mathrm{kyr}$, respectively. 

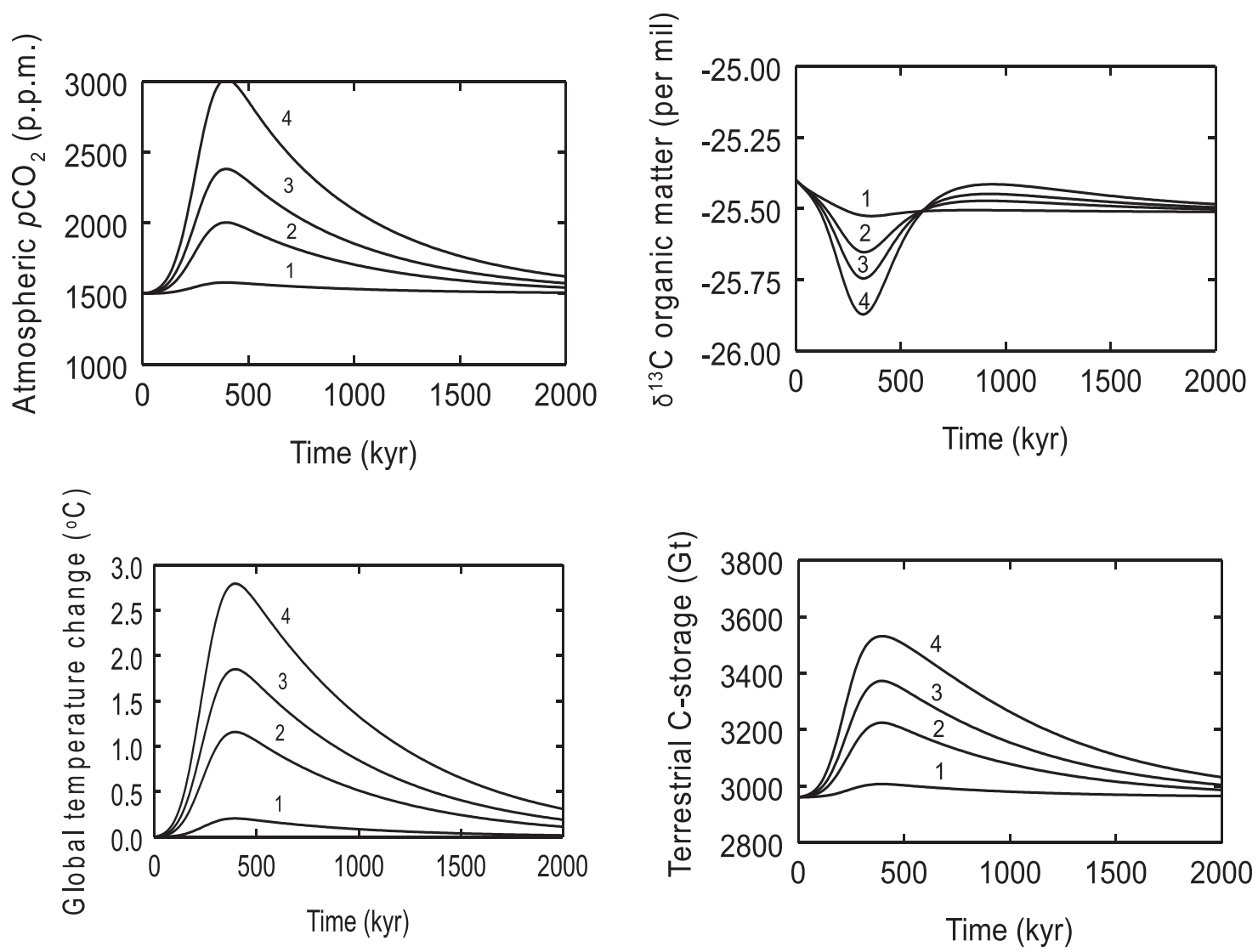

Figure 4. Modeled changes in concentration of atmospheric $\mathrm{CO}_{2}$ ( $p \mathrm{CO}_{2}$, top left), global mean temperatures (bottom left), stable carbon isotope composition of bulk terrestrial organic matter $\left(\delta^{13} \mathrm{C}_{\mathrm{OM}}\right.$, top right), and carbon storage by the terrestrial biosphere (bottom right) in response to $\mathrm{CO}_{2}$ emissions during eruption of Central Atlantic Magmatic Province (CAMP) across Triassic-Jurassic boundary, 200 Myr ago. Lines numbered 1-4 indicate cumulative releases given in Figure 3 and Table 2.

[25] In a separate series of simulations we investigated the possible effects of a suggested [Pálfy et al., 2001, 2002] $\mathrm{CH}_{4}$ release from seafloor sedimentary methane hydrate reservoirs. We assigned an arbitrary lag time of $50 \mathrm{kyr}$ for delay between peak volcanic degassing and $\mathrm{CH}_{4}$ addition to the atmosphere. Identification and dating of other episodic $\mathrm{CH}_{4}$ events in the geologic record during the Latest Paleocene Thermal Maximum [Norris and Röhl, 1999] and the Late Jurassic [Hesselbo et al., 2000; Padden et al., 2001] indicate that the isotopic excursion typically occurs over 100 kyr. Therefore we set the degassing peak for $F_{m}$ at $300 \mathrm{kyr}$ after the start of a simulation with a peak half-height time of $\pm 20 \mathrm{kyr}$ (Figure 3). This means that essentially all $\mathrm{CH}_{4}$ degassing occurred between 300 and $400 \mathrm{kyr}$ after the start of each simulation.

\section{Results and Discussion}

\subsection{Environmental Effects of $\mathrm{CO}_{2}$ Outgassing}

\section{From CAMP Basalt Eruptions}

[26] Model results indicate that three of the four volcanic $\mathrm{CO}_{2}$ emission scenarios we investigated for the emplacement of the CAMP across the TR-J boundary induced transient changes in some aspects of the global environment (Figure 4 and Table 2). In particular, atmospheric $p \mathrm{CO}_{2}$ increased over the late Triassic value (1500 ppm) by between +500 and $+1500 \mathrm{ppm}$, global mean temperatures increased by $+1.2^{\circ}$ to $+2.8^{\circ} \mathrm{C}$, and terrestrial carbon sequestration increased by +265 to $+571 \mathrm{Gt} \mathrm{C}$ (Table 2). Atmospheric $p \mathrm{CO}_{2}$ levels remain elevated after volcanic $\mathrm{CO}_{2}$ degassing $\left(F_{v}\right)$ returns to the background rate because of the slow consumption of $\mathrm{CO}_{2}$ by weathering and reequilibration of the ocean-atmosphere system with $\mathrm{CaCO}_{3} \cdot \mathrm{CO}_{2}$-enhanced greenhouse warming increases the weathering of silicate rocks and leads to enhanced fluxes of $\mathrm{Ca}^{2+}$ to the ocean and (ultimately) leads to the deposition of excess $\mathrm{CaCO}_{3}$ onto the ocean floor (reactions (i)-(iii)). In effect, $\mathrm{CO}_{2}$ released by CAMP volcanism became buried as marine carbonate. Since global temperatures are dependent on atmospheric $p \mathrm{CO}_{2}$, and terrestrial carbon storage responds to both, these variables all have similar trajectories. The curves indicate that if the volcanic degassing took place over $0.5 \mathrm{Myr}$, then the carbon cycle still required $\sim 2 \mathrm{Myr}$ for a complete return of $\mathrm{CO}_{2}$ to a lower steady state concentration.

[27] We calculate that the CAMP eruptions, limited by the total masses of $\mathrm{CO}_{2}$ estimated by others and listed in Table 1, could have increased atmospheric $p \mathrm{CO}_{2}$ by as much as $\sim 850$ ppm above an end-Triassic value of $\sim 1500 \mathrm{ppm}$ (scenario 3 in Figure 4). This is greater than that calculated for the eruption of the Deccan Traps in India during the 
Table 2. Effects of $\mathrm{CO}_{2}$ Outgassing on Global Environment During Emplacement of Central Atlantic Magmatic Province 200 Myr Ago ${ }^{\mathrm{a}}$

\begin{tabular}{|c|c|c|c|c|c|c|c|c|}
\hline \multirow[b]{2}{*}{ Simulation $^{\mathrm{b}}$} & \multicolumn{2}{|c|}{$\begin{array}{c}\text { Atmospheric } p \mathrm{CO}_{2} \\
\text { Level, ppm }\end{array}$} & \multicolumn{2}{|c|}{$\begin{array}{c}\text { Global Mean Temperature } \\
\text { Change }(\Delta T),{ }^{\circ} \mathrm{C} \\
\end{array}$} & \multicolumn{2}{|c|}{$\delta^{13} \mathrm{C}_{\mathrm{om}}, \%$} & \multicolumn{2}{|c|}{$\begin{array}{c}\text { Terrestrial Carbon } \\
\text { Storage, Gt C } \\
\end{array}$} \\
\hline & $\mathrm{CO}_{2}$ & $\mathrm{CO}_{2}+\mathrm{CH}_{4}$ & $\mathrm{CO}_{2}$ & $\mathrm{CO}_{2}+\mathrm{CH}_{4}$ & $\mathrm{CO}_{2}$ & $\mathrm{CO}_{2}+\mathrm{CH}_{4}$ & $\mathrm{CO}_{2}$ & $\mathrm{CO}_{2}+\mathrm{CH}_{4}$ \\
\hline 1 (1326 Gt C) & +78 & +492 & +0.2 & +1.1 & -0.12 & -3.03 & +47 & +259 \\
\hline $2(7957$ Gt C) & +504 & +951 & +1.2 & +1.9 & -0.23 & -2.67 & +265 & +434 \\
\hline $3(13,262 \mathrm{Gt} \mathrm{C})$ & +861 & +1364 & +1.8 & +2.6 & -0.25 & -2.47 & +405 & +543 \\
\hline $4(21,220 \mathrm{Gt} \mathrm{C})$ & +1516 & +2058 & +2.8 & +3.5 & -0.40 & -2.29 & +571 & +622 \\
\hline
\end{tabular}

${ }^{a}$ Results from simulations using carbon cycle model with $\left(\mathrm{CO}_{2}+\mathrm{CH}_{4}\right)$ and without $\mathrm{CH}_{4}$ release. Values are expressed as change relative to Latest Triassic situation: $p \mathrm{CO}_{2}=1500 \mathrm{ppm}$, global mean temperature change $=0.0{ }^{\circ} \mathrm{C}, \delta^{13} \mathrm{C}_{\mathrm{OM}}=-25.4 \%$, and total carbon storage in terrestrial biosphere $=2960 \mathrm{Gt} \mathrm{C}$.

${ }^{\text {b }}$ Simulations correspond to cumulative $F_{v}$ release given in brackets (see also Figure 3). Results with $\mathrm{CO}_{2}$ and $\mathrm{CH}_{4}$ all used same cumulative $F_{m}$ of $5317 \mathrm{Gt} \mathrm{C}$.

end-Cretaceous (200-250 ppm) [Caldeira and Rampino, 1990], because of differences in the mass of $\mathrm{CO}_{2}$ emitted (Table 1), itself a function of the original volume of the basalts and $\mathrm{CO}_{2}$ production rates. For the Deccan Traps, the widely accepted total volume of $2 \times 10^{6} \mathrm{~km}^{3}$ [Wignall, 2001] is better constrained than that for the CAMP basalts [Olsen, 1999]. On the basis of a degassing rate of $1.1 \times 10^{13}$ $\mathrm{g} \mathrm{CO}_{2} \mathrm{~km}^{-3}$ of basalt, Caldeira and Rampino [1990] obtained the 200-ppm rise in atmospheric $\mathrm{CO}_{2}$ under endCretaceous conditions by simulating a total Deccan Traps release of $6000 \mathrm{Gt} \mathrm{C}$. This represents only an intermediate case in our set of scenarios for the CAMP eruptions (Table 1).

[28] The isotopic composition of terrestrial organic matter $\left(\delta^{13} \mathrm{C}_{\mathrm{OM}}\right)$ shows a negative excursion driven by the input to the carbon cycle of isotopically light mantle-derived $\mathrm{CO}_{2}$ (Figure 4). It also shows a very small rise, following the initial drop, which dampens with time. The damped oscillation in $\delta^{13} \mathrm{C}_{\mathrm{OM}}$ is a consequence of the redistribution of ${ }^{13} \mathrm{C}$ among the reservoirs, especially the exchange of carbon between the terrestrial biomass and the atmosphere $\left(F_{\text {bio }}\right)$. Most notable is that the magnitude of the initial $\delta^{13} \mathrm{C}_{\mathrm{OM}}$ excursion, even with the largest input of carbon by volcanic outgassing, is only $-0.4 \%$, which is incompatible with observations $(-2.0$ to $-3.5 \%)$ [McElwain et al., 1999; Pálfy et al., 2001; Ward et al., 2001; Hesselbo et al., 2002]. Changes in $\delta^{13} \mathrm{C}$ values for carbonate, organic matter in marine sediments, and terrestrial organic matter should vary to approximately the same degree due to essentially constant fractionation during photosynthesis and to carbon isotopic equilibrium between the atmosphere and the oceans (see discussion leading to equation (10)).

[29] Similar effects of volcanic emissions on the global carbon isotope system in general have been reported by Kump and Arthur [1999] using an alternative geochemical carbon cycle model. Those authors showed that a huge volcanic $\mathrm{CO}_{2}$ input $(\sim 200,000 \mathrm{Gt} \mathrm{C})$ produces a small negative $\delta^{13} \mathrm{C}$ excursion $(-0.5 \%)$ in marine carbonates. Kump and Arthur [1999], however, obtained a -2\%o excursion in marine $\delta^{13} \mathrm{C}_{\mathrm{OM}}$ due to the use of an asymptotic expression describing the $\mathrm{CO}_{2}$ dependence of photosynthetic isotopic fractionation by marine algae during the synthesis of organic matter. Inclusion of this function in our model increases the magnitude of the $\delta^{13} \mathrm{C}_{\mathrm{OM}}$ excursion by a maximum of only $0.3 \%$ because photosynthetic isotopic fractionation is largely saturated at the high background atmospheric $p \mathrm{CO}_{2}$ levels of the late Triassic.
[30] A collapse in marine primary production [Pálfy et al., 2001; Ward et al., 2001] would be anticipated to have an additional effect on atmospheric $p \mathrm{CO}_{2}$ [Sarmiento and Toggweiler, 1984] and $\delta^{13} \mathrm{C}_{\mathrm{OM}}$ [Kump, 1991; Kump and Arthur, 1999], which is not considered in the present onebox ocean modeling. Under present-day conditions a collapse in the biological pump results in an increase in $p \mathrm{CO}_{2}$ of from 300 to $\sim 500 \mathrm{ppm}$ [Sarmiento and Toggweiler, 1984]; for a 1500-ppm equilibrated ocean, the analogous increase in $p \mathrm{CO}_{2}$ would be from 1500 to $\sim 2300 \mathrm{ppm}$ due to the greater initial acidity of such an ocean (K. Caldeira, unpublished calculations, 2002). However, because of the high acidity, the surface ocean would immediately begin to dissolve the abundant carbonates in shallow water sediments. Therefore, after equilibration of the surface ocean with $\mathrm{CaCO}_{3}$, the atmospheric $p \mathrm{CO}_{2}$ would drop to only $\sim 1700 \mathrm{ppm}$, giving a rise of $200 \mathrm{ppm}$ (K. Caldeira, unpublished calculations, 2002). Further, the modeling shows that this change in atmospheric $\mathrm{CO}_{2}$ could last only for a few thousand years before other changes accounted for in the present modeling would begin to dominate, including carbonate reequilibration. The instantaneous loss of net production would also result in a sudden loss of the ocean vertical $\delta^{13} \mathrm{C}$ gradient, with surface carbon becoming isotopically lighter [Kump, 1991], but by a maximum of only $\sim 1-1.5 \%$ [D'Hondt et al., 1998]

[31] To test the effect of a collapse in marine productivity on atmospheric $\mathrm{CO}_{2}$ and $\delta^{13} \mathrm{C}$ over the longer term, the organic subcycle was added to the modeling and was unbalanced by letting the sedimentation and burial of organic matter go to zero for a long time, between 300 and $700 \mathrm{kyr}$, while the weathering of sedimentary organic carbon continued during this period at the previous rate of $2 \times 10^{18}$ mol $\mathrm{Myr}^{-1}$ [Berner and Kothavala, 2001]. This maximum effect was a rise of the peak $\mathrm{CO}_{2}$ value by $\sim 200 \mathrm{ppm}$ and a further lowering of the negative peak value of $\delta^{13} \mathrm{C}$ by about $-0.5 \%$. Therefore we suggest that any effects of the collapse in marine primary production on $\mathrm{CO}_{2}$ and the negative isotopic anomaly would be relatively rather small, including the initial changes occurring right after the collapse.

\subsection{Transient $\mathrm{CO}_{2}$ Fertilization of Chemical Weathering by Terrestrial Plants}

[32] The biogeochemical weathering of minerals is brought about by plants and the mycorrhizal fungi attached to their roots. Experimental work has shown that in situ 

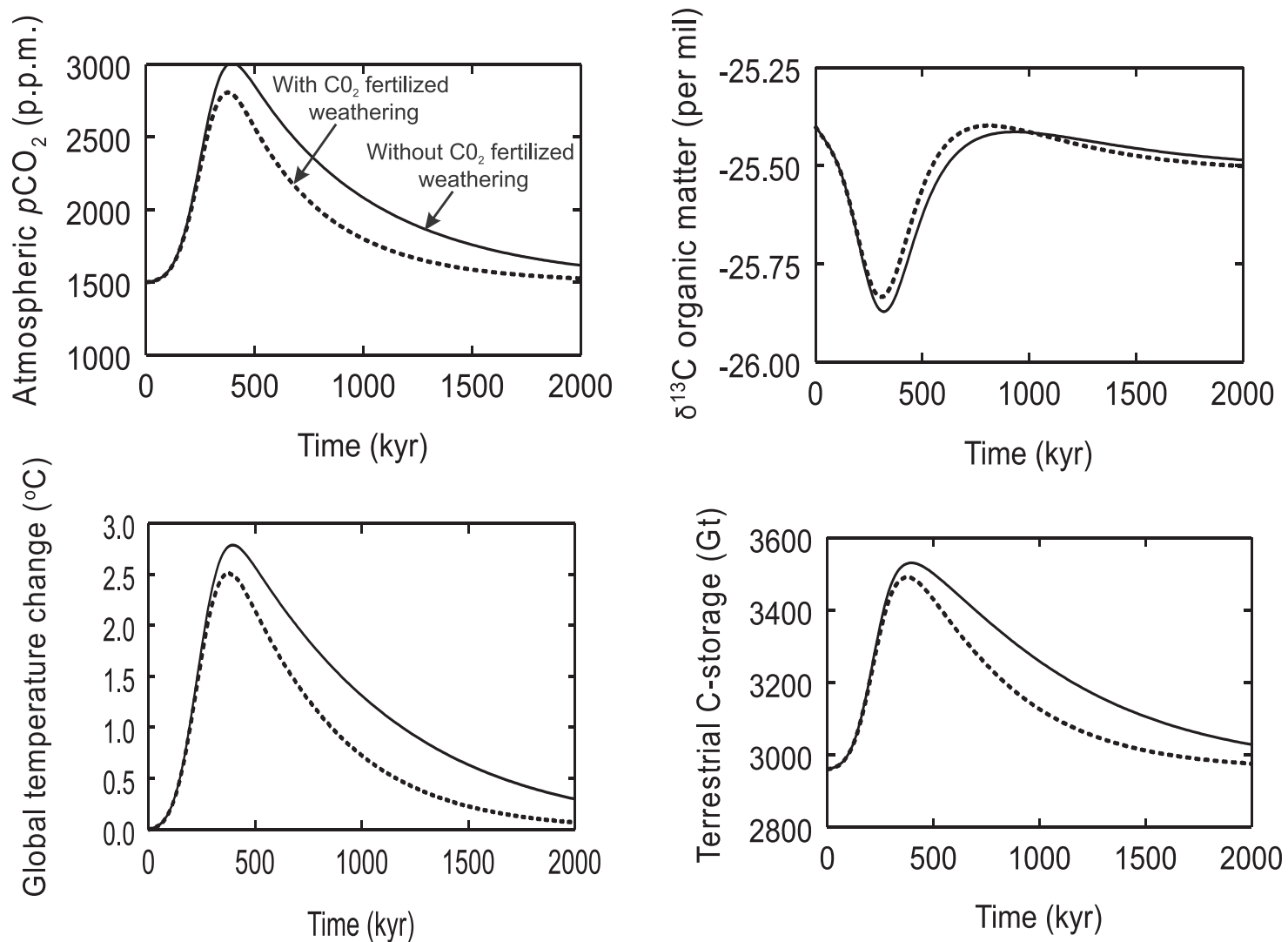

Figure 5. Effects of including (dotted line) and excluding (solid line) $\mathrm{CO}_{2}$ fertilization of plantweathering on the concentration of atmospheric $\mathrm{CO}_{2}\left(p \mathrm{CO}_{2}\right.$, upper left hand panel), global mean temperatures (lower left hand panel), the stable carbon isotope composition of bulk terrestrial organic matter $\left(\delta^{13} \mathrm{C}_{\mathrm{OM}}\right.$, upper right hand panel) and carbon storage by the terrestrial biosphere (lower right hand panel) in response to $\mathrm{CO}_{2}$ emissions during the eruption of the CAMP across the Triassic-Jurassic boundary, $200 \mathrm{Myr}$ ago. Results are shown for scenario 4 (Figure 3, Table 2) only.

exposure of a loblolly pine (Pinus taeda) forest to an atmosphere enriched in $\mathrm{CO}_{2}$ by 200 ppm, over 2 years, increased the flux of dissolved inorganic carbon (bicarbonate) to groundwater by 33\% [Andrews and Schlesinger, 2001]. Other studies have demonstrated that as atmospheric $\mathrm{CO}_{2}$ levels increase, more carbon is exported belowground by the plants, increasing the activity and growth of ectomycorrhizal fungi, themselves important weathering agents of forest soils [Landeweert et al., 2001]. It is conceivable therefore that a transient atmospheric $p \mathrm{CO}_{2}$ increase across the TR-J boundary stimulated a negative feedback on $\mathrm{CO}_{2}$ levels by enhancing plant-mediated chemical weathering of terrestrial silicate rocks.

[33] We assessed the strength of this feedback by including a Michaelis-Menton function describing the relationship between vascular plants, $\mathrm{CO}_{2}$, and chemical weathering of Ca-Mg carbonates $\left(F_{\mathrm{wc}}\right)$ and silicates $\left(F_{\mathrm{wsi}}\right)$ [Berner and Kothavala, 2001]. The $F_{\mathrm{wsi}}(T)$ and $F_{\mathrm{wc}}(T)$ terms (equations (4) and (5)) were each modified via multiplication by the weathering feedback term $f_{b(\mathrm{CO} 2)}$ :

$$
f_{b(\mathrm{CO} 2)}=\left[\frac{2 R \mathrm{CO}_{2}}{\left(1+R \mathrm{CO}_{2}\right)}\right]^{\mathrm{FERT}},
$$

where $R \mathrm{CO}_{2}$ is the ratio of mass of $\mathrm{CO}_{2}$ at time $t$ to that at the present $(t=0)$, and FERT is an exponent reflecting the proportion of plants globally that are fertilized by increasing $\mathrm{CO}_{2}$ and accelerated mineral weathering. We set FERT = 0.4, to mimic the results of Andrews and Schlesinger [2001], but applied it to only $\sim 35 \%$ of all land vegetation, to express the fact that fertilization of plant growth can be limited by factors other than $\mathrm{CO}_{2}$, such as light, nutrients, and water.

[34] To maximize any potential effects of equation (11) on the modeled changes in atmospheric $p \mathrm{CO}_{2}$, global mean temperature, $\delta^{13} \mathrm{C}_{\mathrm{OM}}$, and terrestrial carbon storage, we used the highest degassing scenario, giving a cumulative release of 21,220 Gt C (Figure 3). Under this scenario the plant$\mathrm{CO}_{2}$-weathering feedback reduced atmospheric $p \mathrm{CO}_{2}$ levels by $200 \mathrm{ppm}$ and reduced global temperatures by $0.3^{\circ} \mathrm{C}$ compared to the control (without $\mathrm{CO}_{2}$ fertilized weathering) case (Figure 5). Atmospheric $p \mathrm{CO}_{2}$ and temperature effects marginally lower global terrestrial carbon storage (by $\sim 40$ $\mathrm{Gt} \mathrm{C}$ ), and there is virtually no impact on $\delta^{13} \mathrm{C}_{\mathrm{OM}}$ (Figure 5). With the other three scenarios, involving the release of lower amounts of $\mathrm{CO}_{2}$ during the CAMP eruptions, the effects become even lower.

[35] It appears quite plausible that a rise in atmospheric $\mathrm{CO}_{2}$ across the TR-J boundary exerted a negative feedback 

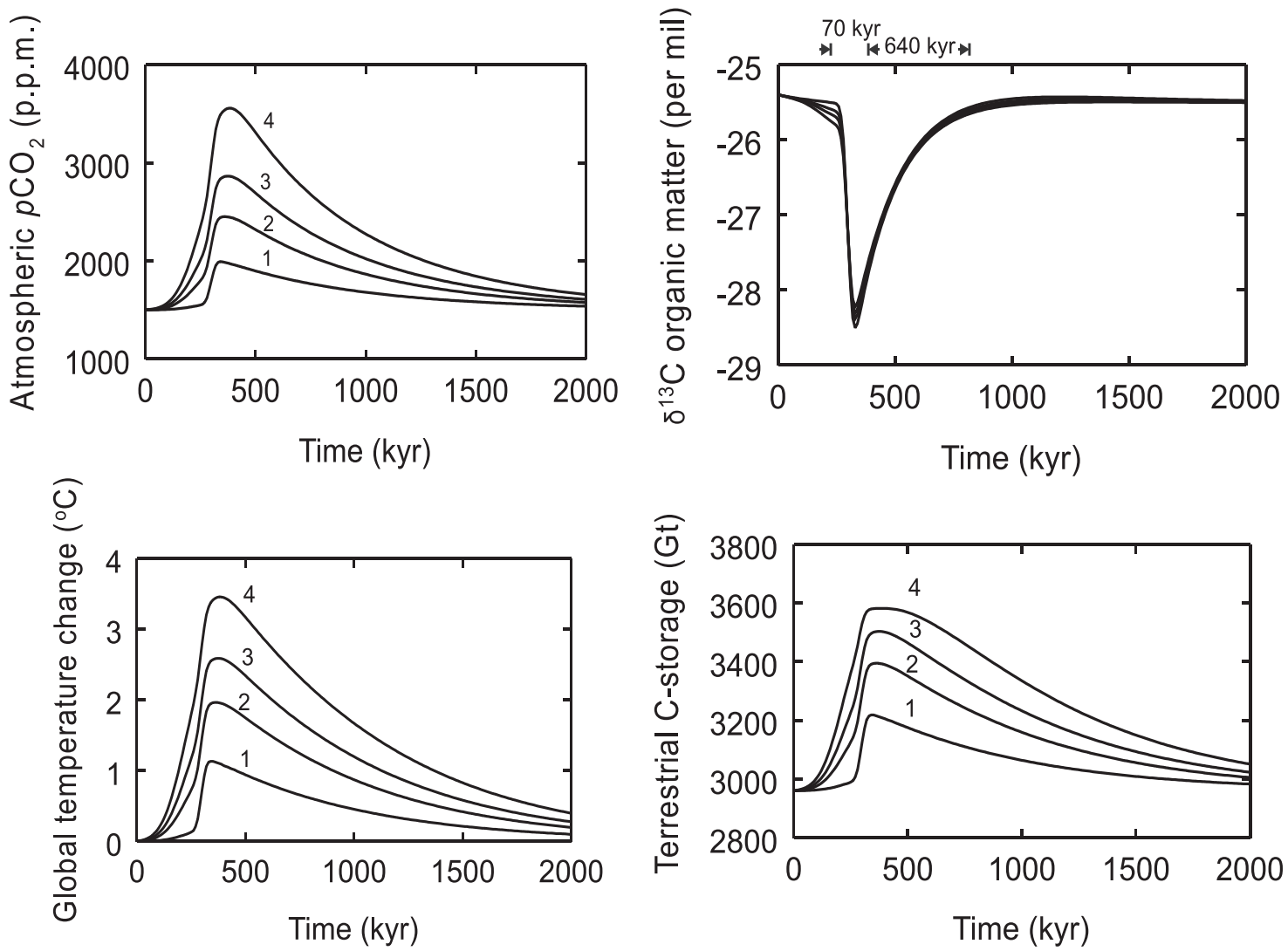

Figure 6. Modeled changes in concentration of atmospheric $\mathrm{CO}_{2}$ ( $p \mathrm{CO}_{2}$, top left), global mean temperature (bottom left), stable carbon isotope composition of bulk terrestrial organic matter $\left(\delta^{13} \mathrm{C}_{\mathrm{OM}}\right.$, top right), and carbon storage by terrestrial biosphere (bottom right) in response to $\mathrm{CO}_{2}$ emissions with a positive feedback including release of $\mathrm{CH}_{4}$ from seafloor hydrates during eruption of CAMP across Triassic-Jurassic boundary, $200 \mathrm{Myr}$ ago. Lines numbered 1-4 indicate the cumulative releases given in Figure 3 and Table 2.

effect by accelerating plant-mediated chemical weathering of sedimentary rocks (Figure 5). The $p \mathrm{CO}_{2}$ drawdown is, however, not significant relative to the $\mathrm{CO}_{2}$ fluxes associated with the volcanic activity. However, this conclusion depends crucially on the proportion of plants at the global scale that behaved like the loblolly pine forest in the experiment of Andrews and Schlesinger [2001], a significant unknown at present.

\subsection{Environmental Effects of $\mathrm{CO}_{2}$ Outgassing With a Positive Feedback on $\mathrm{CH}_{4}$ Release}

[36] Calculations with our greenhouse carbon cycle model indicate that $\mathrm{CO}_{2}$ emissions by volcanism fail to account for the $2.5-3.5 \%$ negative isotopic excursion shown by terrestrial and marine continental sediments [McElwain et al., 1999; Ward et al., 2001; Hesselbo et al., 2002] and the parallel bulk organic matter and carbonates from a Tethyan locality [Pálfy et al., 2001]. Even if we sum the likely contributions of volcanism $\left(-0.4 \%\right.$ ) and $\mathrm{CO}_{2}$ dependence of marine algal carbon isotope fractionation $(-0.3 \%$ ) and allow a negative $0.5 \%$ excursion for a collapse in marine primary production due to the end-Triassic mass extinctions, the final negative isotopic anomaly of $1.2 \%$ is far short of that observed. Climate change related impacts on carbon isotope fractionation by the terrestrial biosphere may also be possible. However, these have not been considered because they will vary at the regional scale depending on the global climate system response to a rise in $\mathrm{CO}_{2}$, and, moreover, the fluxes of carbon involving the terrestrial biosphere are relatively small, so the net effect in the global mass balance (equation (10)) are likely to be correspondingly small.

[37] These considerations indicate the requirement for introducing into the global carbon cycle an isotopically light source of carbon, in addition to mantle-derived $\mathrm{CO}_{2} \cdot \mathrm{CH}_{4}$ is extremely isotopically light $(-60 \%)$ and thus might provide an appropriate carbon input [Pálfy et al., 2001, 2002]. Global warming due to a rise in volcanogenic $\mathrm{CO}_{2}$ could have triggered the release of methane stored in methane hydrates, which was rapidly oxidized to $\mathrm{CO}_{2}$, thereby acting as a positive feedback. The mass of $\mathrm{CH}_{4}$ released from the seafloor across the TR-J boundary under such circumstances is uncertain. Here we determined it by sensitivity analyses and found that to obtain a negative $3 \%$ excursion in $\delta^{13} \mathrm{C}_{\mathrm{OM}}$ under Late Triassic conditions during CAMP $\mathrm{CO}_{2}$ outgassing required the total release of $\sim 5000 \mathrm{Gt} \mathrm{C}$ as $\mathrm{CH}_{4}$ spread over a period of $100 \mathrm{kyr}$ (Figures 2 and 6). Such a massive $\mathrm{CH}_{4}$ release is more than double that implicated in the perturbation of the global carbon cycle during Latest Pale- 
ocene Thermal Maximum (LPTM) (1000-2100 Gt C) [Dickens et al., 1997], but is comparable to that calculated for the isotopic anomalies in early Jurassic sediments [Hesselbo et al., 2002; Beerling et al., 2002].

[38] When this positive feedback is included in the modeling, it amplifies earlier changes in the global environment, compared to the results obtained by $\mathrm{CO}_{2}$ degassing alone (Figure 6 and Table 2). Atmospheric $p \mathrm{CO}_{2}$ levels increased by an additional $400-500 \mathrm{ppm}$, induced further greenhouse warming of up to $0.7^{\circ} \mathrm{C}$, and led to extra carbon sequestration by the terrestrial biosphere of $\sim 200$ Gt (Table 2). Injection into the ocean-atmosphere system of $\sim 5000 \mathrm{Gt} C$ as $\mathrm{CH}_{4}$ accounts for the magnitude of the observed shift in $\delta^{13} \mathrm{C}_{\mathrm{OM}}$, but also adds structure to the curve (Figure 6). The curve now shows an abrupt initial decline to its most negative value over a period of $\sim 70 \mathrm{kyr}$, followed by a slower period of recovery of $\sim 640 \mathrm{kyr}$ (Figure 6 ). The overall pattern is reminiscent of that shown by high-resolution carbon isotope records across the LPTM (reviewed by Dickens [2001]). That event, however, was apparently much shorter, with most of the ${ }^{12} \mathrm{C}$ release taking place over $52 \mathrm{kyr}$ and with the excursion taking $220 \mathrm{kyr}$ to reach steady state [Röhl et al., 2000].

[39] Similar results (within $200 \mathrm{ppm}$ for $\mathrm{CO}_{2}$ and $0.5 \%$ for $\delta^{13} \mathrm{C}$ ) were obtained if $\mathrm{CH}_{4}$ was assumed to be injected directly into the oceans rather than the atmosphere. As in the atmosphere, methane was assumed to be oxidized rapidly, in this case by methanotrophic bacteria. The oxygen demand at the assumed peak of $\mathrm{CH}_{4}$ degassing $\left(100 \mathrm{Gt} \mathrm{kyr}^{-1}\right.$; see Figure 3) is $\sim 20$ times lower than the standing crop of $\mathrm{O}_{2}$ dissolved in the (modern) oceans, and because the oceanic overturn and $\mathrm{O}_{2}$ resupply time is $\sim 1 \mathrm{kyr}$, it is unlikely that $\mathrm{CH}_{4}$ oxidation led to an appreciable depletion of oceanic $\mathrm{O}_{2}$. Thus we have ignored depletion of oceanic $\mathrm{O}_{2}$ that otherwise could lead to somewhat different results [Dickens, 2000].

[40] Further analysis of the two sets of model results (with and without $\mathrm{CH}_{4}$ release) indicates that the rise in atmospheric $p \mathrm{CO}_{2}$ and global mean temperature are linearly related to the total mass of $\mathrm{CO}_{2}$ released during the extrusion of the CAMP basalts (Figure 7). Inclusion of $\mathrm{CH}_{4}$ addition to the ocean-atmosphere system simply displaces the line upward for each variable. From Figure 7 it can be seen that an atmospheric $p \mathrm{CO}_{2}$ rise of $\sim 1000 \mathrm{ppm}$, based on our stomatal index and paleosol-derived estimations, requires the cumulative release of $8000-9000 \mathrm{Gt} \mathrm{C}$ as $\mathrm{CO}_{2}$ across the TR-J boundary, in addition to release of sedimentary $\mathrm{CH}_{4}$. Our synthesis of model simulations (Figure 7), and the paleo-evidence, indicates, therefore, that the actual amount of $\mathrm{CO}_{2}$ degassing during the emplacement of the CAMP volcanic basalts has been underestimated (Table 1) and/or that the original volume of the province lies, as suspected [Marzoli et al., 1999; Olsen, 1999], somewhere between 2 and $4 \times 10^{6} \mathrm{~km}^{3}$.

\subsection{Wider Issues}

[41] If our proposed sequence of events for a massive carbon cycle perturbation across the TR-J boundary is correct, it places the duration for the atmospheric $p \mathrm{CO}_{2}$ and $\delta^{13} \mathrm{C}_{\mathrm{OM}}$ excursions at between 700 and $1000 \mathrm{kyr}$ (Figure 6). Dating of the duration of the Rhaetian and
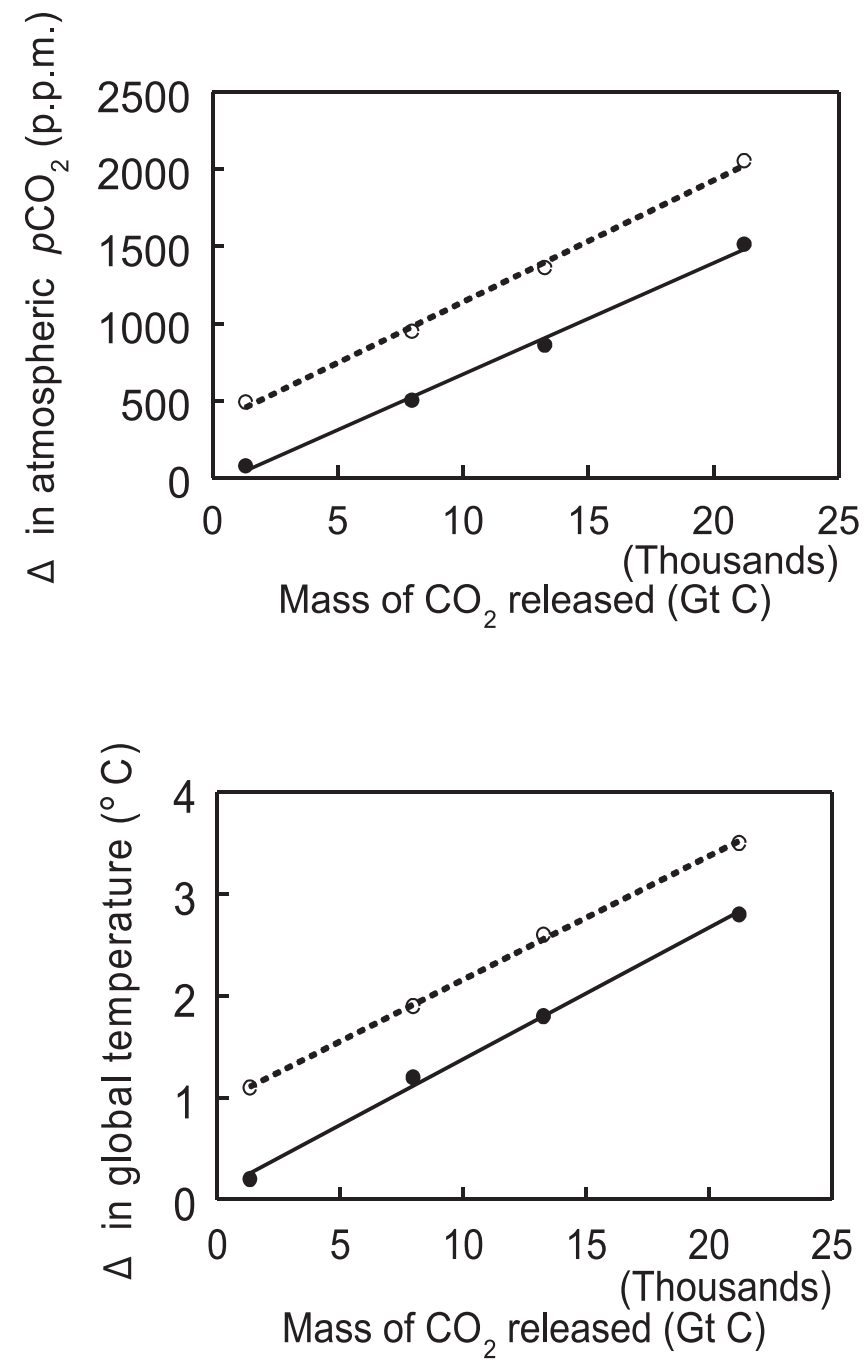

Figure 7. Maximum change in atmospheric $\mathrm{CO}_{2}$ level ( $p \mathrm{CO}_{2}$, top) and global mean temperatures (bottom) to total mass of $\mathrm{CO}_{2}$ released during the extrusion of CAMP under end-Triassic greenhouse conditions. In each case, results for $\mathrm{CO}_{2}$ only (solid line) and $\mathrm{CO}_{2}+\mathrm{CH}_{4}$ release (dashed line) are depicted. Regression details: (top) $\mathrm{CO}_{2}$ only case: slope $=0.072$, intercept $=-49.78(r=0.99) ; \mathrm{CO}_{2}+\mathrm{CH}_{4}$ case: slope, $=0.079$, intercept $=353.38(r=0.99)$; (bottom) $\mathrm{CO}_{2}$ only case: slope $=0.00013$, intercept $=0.0858(r=0.99)$; $\mathrm{CO}_{2}+\mathrm{CH}_{4}$ case: slope $=0.00012$, intercept $=0.948(r=$ 0.99 ).

Hettangian stages differ, with Harland et al. [1990] giving 2 and 4.5 Myr, respectively, Gradstein et al. [1994] giving 3.9 and $3.8 \mathrm{Myr}$, and Pálfy et al. [2000b] reporting, on the basis of radiometric dates, a duration of $3.1 \mathrm{Myr}$ for the Hettangian. All indications suggest that the TR-J boundary isotopic and $p \mathrm{CO}_{2}$ fingerprints occur within only part of the Rhaetian and Hettangian stages. Therefore our timescale for the carbon cycle dynamics of the event is certainly compatible with all of these considerations. Indeed, a preliminary timescale attached to the $\delta^{13} \mathrm{C}_{\mathrm{OM}}$ signal at the Kennecott Point section in Canada suggests a total duration for the 
excursion of $\sim 500 \mathrm{kyr}$ [Ward et al., 2001] and for the sudden extinction of radiolarians of $50 \mathrm{kyr}$, the latter being comparable to that modeled for initial $\delta^{13} \mathrm{C}_{\mathrm{OM}}$ excursion with the inclusion of $\mathrm{CH}_{4}$ release (70 kyr) (Figure 6).

[42] A rise in atmospheric $p \mathrm{CO}_{2}$ of $1000 \mathrm{ppm}$, and a global greenhouse warming of $2^{\circ}-2.5^{\circ} \mathrm{C}$, occurring against a background $p \mathrm{CO}_{2}$ level of $\sim 1000-1500 \mathrm{ppm}$, represents a highly challenging environment for land plants, especially in the hothouse world of late Triassic Pangea. These changes in the global environment indicate that high temperature damage to large leaved plant taxa, hypothesized to underlie the ecological crisis [McElwain et al., 1999], continues to remain a real possibility. Under this scenario, large entireleaved canopy-dominant plants suffered severe temperature damage to the photosynthetic system, especially during periods of low wind speeds, because of their innate low boundary layer conductances and limited convective cooling capacities. The leaf megafossil record from Greenland [Harris, 1935, 1937; Lundblad, 1959] clearly supports this notion by indicating a pattern of species extinction and replacement whereby large-leaved taxa were lost and replaced by those with more dissected or finely divided leaves. We can envisage no plausible mechanism for disturbing the carbon cycle, or the global climate system, consistent with the available geologic data, that supports the suggestion, based on multivariate analyses and climate correlations of sporomorphs [Hubbard and Boulter, 2000], that the global climate actually cooled across the TR-J boundary.

\section{Conclusion}

[43] We conclude from our series of carbon cycle simulations for an end-Triassic greenhouse world that $\mathrm{CO}_{2}$ release from the Earth's mantle during the extrusion of the CAMP basalts across the TR-J boundary, $200 \mathrm{Myr}$ ago, was probably insufficient to fully account for the $\sim 1000 \mathrm{ppm}$ rise in atmospheric $p \mathrm{CO}_{2}$ indicated by stomatal and paleosol evidence. Furthermore, the cumulative injection of a wide range of $\mathrm{CO}_{2}$ masses over $500 \mathrm{kyr}$ failed to reproduce the negative $\delta^{13} \mathrm{C}$ anomaly seen in marine and terrestrial sedimentary carbon across the TR-J boundary. This conclusion holds even when the model is modified to account for the effects of an instantaneous cessation of organic carbon burial due to a drop in productivity and for the effects of atmospheric $p \mathrm{CO}_{2}$ on carbon isotope fractionation by marine algae. If $\mathrm{CO}_{2}$ degassing occurred over $>500 \mathrm{kyr}$, the effects would be even less than simulated here.

[44] The scenario that best explains the geologic evidence is global warming due to a buildup of volcanically derived $\mathrm{CO}_{2}$ in the atmosphere, triggering a positive feedback whereby seafloor methane hydrate reservoirs become destabilized and release massive amounts of $\mathrm{CH}_{4}$ into the oceanatmosphere system. Our analyses suggest that this sequence of events involved the release of $\sim 8000-9000 \mathrm{Gt} \mathrm{C}$ as gaseous $\mathrm{CO}_{2}$ during the eruption of the CAMP continental flood basalts and an injection of $\sim 5000 \mathrm{Gt} \mathrm{C}$ from the methane hydrate reservoir. Together, the net effects were a transient peak in atmospheric $p \mathrm{CO}_{2}$ in excess of $2500 \mathrm{ppm}$ and a greenhouse warming of $2^{\circ}-2.5^{\circ} \mathrm{C}$ above end-Triassic conditions. Reequilibrium of the ocean-atmosphere system was accomplished over 700-1000 kyr. Our theoretical results therefore provide a preliminary explanation for the estimated $p \mathrm{CO}_{2}$ excursion and for the duration for the isotopic signal observed in sediments.

[45] Acknowledgments. D. J. B. gratefully acknowledges funding through a Royal Society University Research Fellowship and the Leverhulme Trust, and R. A. B. gratefully acknowledges financial support by the NSF grant EAR-0104797 and DOE grant DE-FG02-01ER15173. We have benefited greatly from the comments of $\mathrm{K}$. Caldeira, including unpublished calculations that he provided to us. This is a contribution to the International Geological Correlation Programme Project 458.

\section{References}

Andrews, J. A., and W. H. Schlesinger, Soil $\mathrm{CO}_{2}$ dynamics, acidification, and chemical weathering in a temperate forest with $\mathrm{CO}_{2}$ enrichment, Global Biogeochem. Cycles, 15, 149-162, 2001.

Beerling, D. J., Global terrestrial productivity in the Mesozoic era, in $\mathrm{Cli}$ mates: Past and Present, edited by M. B. Hart, Geol. Soc. Spec. Publ., 181, 17-32, 2000 .

Beerling, D. J., Palaeoclimatology: $\mathrm{CO}_{2}$ and the end-Triassic mass extinction, Nature, 415, 386-387, 2002.

Beerling, D. J., and D. L. Royer, Fossil plants as indicators of the Phanerozoic global carbon cycle, Ann. Rev. Earth Planet. Sci., 30, 527-556, 2002.

Beerling, D. J., M. R. Lomas, and D. R. Grocke, On the nature of methane gas dissociation during the Toarcian and Aptian oceanic anoxic events, Am. J. Sci., in press, 2002.

Berner, R. A., GEOCARB II: A revised model of atmospheric $\mathrm{CO}_{2}$ over Phanerozoic time, Am. J. Sci., 294, 56-91, 1994.

Berner, R. A., The carbon cycle and $\mathrm{CO}_{2}$ over Phanerozoic time: The role of land plants, Philos. Trans. R. Soc. London, Ser. B, 353, 75-82, 1998.

Berner, R. A., and Z. Kothavala, GEOCARB III: A revised model of atmospheric $\mathrm{CO}_{2}$ over Phanerozoic time, Am. J. Sci., 301, 182-204, 2001.

Berner, R. A., A. C. Lasaga, and R. M. Garrels, The carbonate-silicate geochemical cycle and its effect on atmospheric carbon dioxide over the past 100 million years, Am. J. Sci., 283, 641-683, 1983.

Caldeira, K. G., and M. R. Rampino, Deccan volcanism, greenhouse warming, and the Cretaceous-Tertiary boundary, in Global Catastrophes in Earth History, edited by V. L. Sharpton and P. D. Ward, pp. 117-123, Spec. Pap. Geol. Soc. Am., 247, 1990.

Cerling, T. E., Carbon dioxide in the atmosphere: Evidence from Cenozoic and Mesozoic paleosols, Am. J. Sci., 291, 377-400, 1991.

Cerling, T. E., Use of carbon isotopes in paleosols as an indicator of the $p\left(\mathrm{CO}_{2}\right)$ of the paleo-atmosphere, Global Biogeochem. Cycles, 6, 307314, 1992.

Chaloner, W. G., and J. C. McElwain, The fossil plant record and global climatic change, Rev. Palaeobot. Palynol., 95, 73-82, 1997.

Cohen, A. S., and A. L. Coe, New geochemical evidence for the onset of volcanism in the Central Atlantic Magmatic Province and environmental change at the Triassic-Jurassic boundary, Geology, 30, 267-270, 2002.

Deckart, K., G. Féraud, and H. Bertrand, Age of Jurassic continental tholeiites of French Guyana, Surinam, and Guinea: Implications for the initial opening of the Central Atlantic Ocean, Earth Planet. Sci. Lett., 150, 205-220, 1997.

D'Hondt, S. D., P. Donaghay, J. C. Zachos, D. Luttenberg, and M. Lindinger, Organic carbon fluxes and ecological recovery from the CretaceousTertiary mass extinction, Science, 282, 276-279, 1998.

Dickens, G. R., Methane oxidation during the Late Palaeocene Thermal Maximum, Bull. Soc. Geol. Fr., 171, 37-49, 2000.

Dickens, G. R., Carbon addition and removal during the Late Palaeocene Thermal Maximum: Basic theory with a preliminary treatment of the isotope record at ODP site 1051, Blake Nose, in Western North Atlantic Palaeocene and Cretaceous Palaeoceanography, edited by D. Kroon, R. D. Norris, and A. Klaus, Geol. Soc. Spec. Publ., 183, 293-305, 2001.

Dickens, G. R., M. M. Castillo, and J. C. G. Walker, A blast of gas in the latest Paleocene: Simulating first-order effects of massive dissociation of methane hydrate, Geology, 25, 259-262, 1997.

Edwards, D. E., Climate signals in Palaeozoic land plants, Philos. Trans. R. Soc. London, Ser. B, 353, 141-157, 1998

Ekart, D. D., T. E. Cerling, I. P. Montanez, and N. J. Tabor, A 400 million year carbon isotope record of pedogenic carbonate: Implications for paleoatmospheric carbon dioxide, Am. J. Sci., 299, 805-827, 1999. 
Fowell, S. J., and P. E. Olsen, Time calibration of Triassic-Jurassic microfloral turnover, eastern North America, Tectonophysics, 222, 361-369, 1993.

Gerlach, T. M., and E. J. Graeber, Volatile budget of Kilauea volcano, Nature, 313, 273-277, 1985.

Gradstein, F. M., F. P. Agterberg, J. G. Ogg, J. Hardenbol, P. van Veen, J. Thierry, and Z. Huang, A Mesozoic timescale, J. Geophys. Res., 99, 24,051-24,074, 1994.

Hallam, A., and P. B. Wignall, Mass Extinctions and Their Aftermath, Oxford Univ. Press, New York, 1997.

Hames, W. E., P. R. Renne, and C. Ruppel, New evidence for geologically instantaneous emplacement of earliest Jurassic Central Atlantic Magmatic Province basalts on the North American margin, Geology, 28, 859-862, 2000.

Harland, W. B., R. L. Armstrong, A. V. Cox, L. E. Craig, A. G. Smith, and D. G. Smith, A Geologic Timescale: 1989, Cambridge Univ. Press, New York, 1990.

Harris, T. M., The fossil flora of Scoresby Sound East Greenland, 4, Ginkgoales, Coniferales, Lycopodiales, and isolated fructifications, Medd. Grøenl., 112(1), 1-176, 1935.

Harris, T. M., The fossil flora of Scoresby Sound East Greenland, 5, Stratigraphic relations, Medd. Grøenl., 112(2), 1-114, 1937.

Hesselbo, S. P., D. R. Gröcke, H. C. Jenkyns, C. J. Bjerrum, P. Farrimond, H. S. Morgans Bell, and O. R. Green, Massive dissociation of gas hydrate during a Jurassic oceanic anoxic event, Nature, 406, 392-395, 2000.

Hesselbo, S. P., S. A. Robinson, F. Surlyk, and S. Piasecki, Terrestrial and marine extinction at the Triassic-Jurassic boundary synchronized with a major carbon-cycle perturbation: A link to initiation with massive volcanism, Geology, 30, 251-254, 2002.

Holser, W. T., et al., A unique geochemical record at the Permian-Triassic boundary, Nature, 337, 39-44, 1989.

Hsü, K. J., et al., Mass mortality and its environmental and evolutionary consequences, Science, 216, 249-256, 1982.

Hubbard, R. N. L. B., and M. C. Boulter, Phytogeography and paleoecology in western Europe and eastern Greenland near the Triassic-Jurassic boundary, Palaios, 15, 120-131, 2000.

Kump, L. R., Interpreting carbon-isotope excursions: Strangelove oceans, Geology, 19, 299-302, 1991

Kump, L. R., and M. A. Arthur, Interpreting carbon-isotope excursions: Carbonates and organic matter, Chem. Geol., 161, 181-198, 1999.

Landeweert, R., E. Hoffland, R. D. Finlay, T. W. Kuyper, and N. van Breemen, Linking plants to rocks: Ectomycorrhizal fungi mobilize nutrients from minerals, Trends Ecol. Evol., 16, 248-254, 2001.

Leavitt, S. W., Annual volcanic carbon dioxide emissions: An estimate from eruptions chronologies, Environ. Geol., 4, 15-21, 1982.

Lundblad, A. B., Studies in the Rhaeto-Liassic floras of Sweden, K. Sven. Vetenskapsakad. Handl., 6, 1-18, 1959.

Marzoli, A., P. R. Renne, E. M. Piccirillo, M. Ernesto, G. Bellieni, and A. D. Min, Extensive 200-million-year-old continental flood basalts of the Central Atlantic Magmatic Province, Science, 284, 616-618, 1999.

McElwain, J. C., Do fossil plants signal palaeoatmospheric $\mathrm{CO}_{2}$ concentration in the geological past?, Philos. Trans. R. Soc. London, Ser. B, 353, 83-96, 1998.

McElwain, J. C., and W. G. Chaloner, The fossil cuticle as a skeletal record of environmental change, Palaios, 11, 376-388, 1996.

McElwain, J. C., D. J. Beerling, and F. I. Woodward, Fossil plants and global warming at the Triassic-Jurassic boundary, Science, 285, 13861390, 1999.

McHone, J. G., Broad-terrane Jurassic flood basalts across north-eastern North America, Geology, 24, 319-322, 1996.

McRoberts, C. A., H. Furrer, and D. S. Jones, Palaeoenvironmental interpretation of a Triassic-Jurassic boundary section from western Austria based on palaeoecological and geochemical data, Palaeogeogr. Palaeoclimatol. Palaeoecol., 136, 79-95, 1997.
Norris, R. D., and U. Röhl, Carbon cycling and chronology of climate warming during the Palaeocene/Eocene transition, Nature, 401, 775$778,1999$.

Olsen, P. E., Giant lava flows, mass extinctions and mantle plumes, Science, 284, 604-605, 1999.

Olsen, P. E., R. W. Schlische, and M. S. Fedosh, 580 ky duration of the Early Jurassic flood basalt event in eastern North America estimated using Milankovitch cyclostratigraphy, in The Continental Jurassic, edited by M. Morales, pp. 11-22, Bull.60, Mus. of North. Ariz., Flagstaff, Ariz., 1996.

Padden, M., H. Weissert, and M. Rafelis, Evidence for Late Jurassic release of methane from gas hydrate, Geology, 29, 223-226, 2001.

Pálfy, J., J. K. Mortensen, E. S. Carter, P. L. Smith, R. M. Friedman, and H. W. Tipper, Timing of the end-Triassic mass extinctions: First on land then in the sea?, Geology, 28, 39-42, 2000a.

Pálfy, J., P. L. Smith, and J. K. Mortensen, A U-Pb and ${ }^{40} \mathrm{Ar} /{ }^{39} \mathrm{Ar}$ time scale for the Jurassic, Can. J. Earth Sci., 37, 923-944, 2000b.

Pálfy, J., A. Demény, J. Haas, M. Hetényi, M. J. Orchard, and I. Vetõ, Carbon isotope anomaly and other geochemical changes at the TriassicJurassic boundary, Geology, 29, 1047-1050, 2001.

Pálfy, J., P. L. Smith, and J. K. Mortensen, Dating the end-Triassic and Early Jurassic mass extinctions, correlative large igneous provinces, and isotopic events, in Catastrophic Events and Mass Extinctions, edited by C. Koeberl and K. MacLeod, Spec. Pap. Geol. Soc. Am., in press, 2002.

Röhl, U., T. J. Bralower, R. D. Norris, and G. Wefer, New chronology for the late Paleocene thermal maximum and its environmental implications, Geology, 28, 927-930, 2000.

Royer, D. L., R. A. Berner, and D. J. Beerling, Phanerozoic atmospheric $\mathrm{CO}_{2}$ change: Evaluating geochemical and paleobiological approaches, Earth Sci. Rev., 54, 349-392, 2001.

Sarmiento, J. L., and J. R. Toggweiler, A new model for the role of the oceans in determining atmospheric $p \mathrm{CO}_{2}$, Nature, 356, 589-593, 1984.

Schrag, D. P., R. A. Berner, P. F. Hoffman, and G. P. Halvorsen, On the initiation of a snowball Earth, Geochem. Geophys. Geosyst., in press, 2002.

Sepkosky, J. J., Patterns of Phanerozoic extinction: A perspective from global databases, in Global Events and Event Stratigraphy, edited by O. H. Walliser, pp. 35-51, Springer-Verlag, New York, 1996.

Suchecki, R. K., J. F. Hubert, and C. C. Birney de Wit, Isotopic imprint of climate and hydrogeochemistry on terrestrial strata of the Triassic-Jurassic Hartford and Fundy rift basins, J. Sediment Petrol., 58, 801-811, 1988.

Tanner, L. H., J. F. Hubert, and B. P. Coffey, Stability of atmospheric $\mathrm{CO}_{2}$ levels across the Triassic-Jurassic boundary, Nature, 411, 675-677, 2001.

Visscher, H., and W. A. Brugman, Ranges of selected palynofloras in the Alpine Triassic of Europe, Rev. Paleobot. Palynol., 34, 115-128, 1981.

Ward, P. D., J. W. Haggart, E. S. Carter, D. Wilbur, H. W. Tipper, and T. Evans, Sudden productivity collapse associated with the Triassic-Jurassic boundary mass extinction, Science, 292, 1148-1151, 2001.

Wignall, P. B., Large igneous provinces and mass extinctions, Earth Sci. Rev., 53, 1-33, 2001 .

Woodward, F. I., Stomatal numbers are sensitive to increases in $\mathrm{CO}_{2}$ from pre-industrial levels, Nature, 327, 617-618, 1987.

Woodward, F. I., T. M. Smith, and W. R. Emanuel, A global land primary productivity and phytogeography model, Global Biogeochem. Cycles, 9, 471-490, 1995.

D. J. Beerling, Department of Animal and Plant Sciences, University of Sheffield, Sheffield S10 2TN, UK. (d.j.beerling@sheffield.ac.uk)

R. A. Berner, Department of Geology and Geophysics, Yale University, P.O. Box 208109, New Haven, CT 06520-8109, USA. (robert.berner@ yale.edu) 